\title{
THE INFLUENCE OF DISTRIBUTIOIN AND ECOLOGY ON THE THERMOREGULATION OF SMALL BIRDS
}

By

CHARLES GERALD YARBROUGH

\begin{abstract}
A DISSERTATION PRESENTED TO THE GRADUATE COUNCIL OF
THE UNIVERSITY OF FLORIDA

IN PARTLAL FULFILLMENT OF THE REQUIREMENTS FOR THE DEGREE OF DOCTOR OF PHILOSOPHY
\end{abstract}

UNIVERSITY OF FLORIDA

1970 

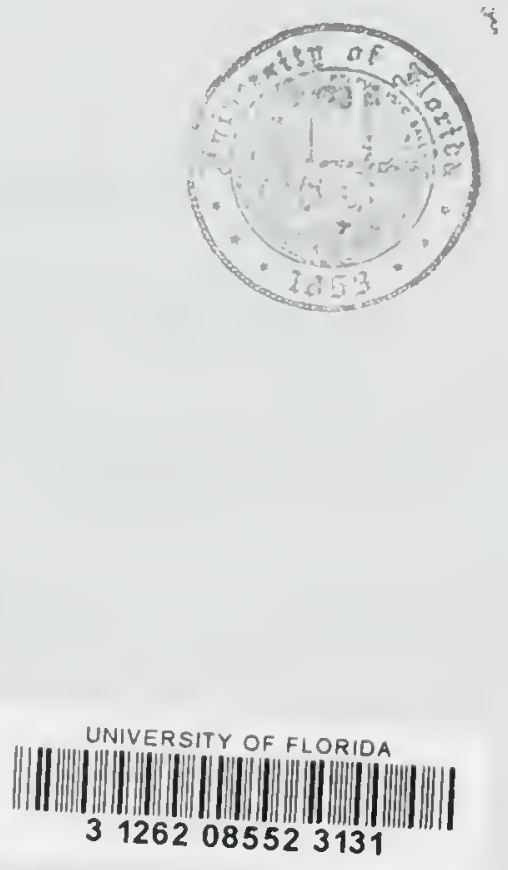


\section{ACKINOWLEDGMENTS}

I have profited from many discussions with David $W$. Johnston and Brian K. MCNab. Dr. MCNab also provided the data on the Black-throated Trogon. David Niles and S. A. Rohwer of the University of Kansas kindly obtained the Harris' Sparrows for me. The equipment and facilities of the University of Florida were used throughout the study. The work was done while in tenure of a National Science Foundation rraineeship. I wish to credit my wife, riazel, for her constant encouragement. 


\section{TABLE, OF CONTENTS}

Acknowledgements

List of Tables

List of Figures

Abstract

viii

Introduction

Materials and Methods

Results

Discussion

Heat Loss and Heat Gain

Metabolism

Conductance

The Physical Model 36

Determination of the Level of $\mathrm{T}_{\mathrm{b}}$

Body Size Effects 44

Precision of $T_{b}$ Regulation 45

Ecological and Distributional Relationships 51

Conclusions and Simmary 56

Appendix A - Symbols and Fxpressions Employed 59

in This Paper

Appendix 5 - Scientific and Common Names for

Species Discussed in This study 


\section{LIST OF TABLES}

Table 1 Parameters of the energetics of $\mathrm{T}_{\mathrm{b}}$

regulation in some small birds

Table 2 Energetic parameters of small birds

selected from the Iiterature 


\section{LIST OF FIGURES}

Figure 1 Responses of body temperature and oxygen consumption to ambient temperature in Spizelza passerina and Zonotrichia albicolzis.

Figure 2 Responses of body temperature and oxygen consumption to ambient temperature in

Passerculus sandwichensis and Ammodramus savannarum.

Figure 3 Responses of body temperature and oxygen consumption to ambient temperature in Me Zospiza meZodia and Melospiza georgiana.

Figure 4 Responses of body temperature and oxygen consumption to ambient temperature in Pooecetes gramineus and Passerezla iziaca.

Figure 5 Responses of body temperature and oxygen consumption to ambient temperature in Zonotrichia querula and Zonotrichia Zeucophrys.

Figure 6 Responses of body temperature and oxygen consumption to ambient temperature in Paruia americana and Vermivora pinus.

Figure 7 Responses of body temperature and oxygen consumption to ambient temperature in Dendroica pinus, Vemivora celata, and Mniotizta varia. 
Figure 8 Responses of body temperature and oxygen consumption to ambient temperature in Dendroica coronata and Protonotaria citrea.

Figure 9 Responses of body temperature and oxygen consumption to ambient temperature in Wilsonia citrina and Dendroica dominica.

Figure 10 Responses of body temperature and oxygen consumption to ambient temperature in seiurus noveboracensis and seiurus aurocapizzus.

Figure 11 Responses of body temperature and oxygen consumption to ambient temperature in Dendroica palmarum and Trogon rufus.

Figure 12 Responses of body temperature and oxygen consumption to ambient temperature in Sayornis phoebe and Geothrypis trichas.

Figure 13 Responses of body temperature and oxygen consumption to ambient temperature in Empidonax virescens and Contopus virens. Figure 14 Responses of body temperature and oxygen consumption to ambient temperature in Myiarchus crinitus and Tyrannus tyrannus. Figure 15 The relation of basal metabolic rate to body weight in some small birds.

Figure 16 The relation of thermal conductance to body weight in some smal]. birds. 
Figure 17 The relation of the observed thermo-

regulatory quotient $\left(\mathrm{M}_{\mathrm{b}} / \mathrm{C}\right)$ 。 to body

weight in some small birds.

Figure 18 A plot showing the effect of body weight

on thermoregulation data taker. irom birds

used in this study and from the literature.

Figure 19 The relation of the extent of the thermal

buffer to the thermoregulatory guotient

expected from body size alone.

Figure 20 A plot of the extent to which body temper-

ature is buffered, as a function of the

combined ratios $\left(\mathrm{M}_{\mathrm{b}} / \mathrm{C}\right)_{\mathrm{r}}$ and $\left(\mathrm{M}_{\mathrm{b}} / \mathrm{C}\right)_{e}$.

Figure 21 A plot of the degree of sensitivity of body 50 temperature to changes in ambient temperature $\left(\Delta \mathrm{T}_{\mathrm{b}} / \Delta \mathrm{T}_{\mathrm{a}}\right)$ as a function of body size $\left(\mathrm{H}_{\mathrm{b}} / \mathrm{C}\right)_{e}$ in some small birds.

Figure 22 The relation of body weight and the ratio

$\left(\mathrm{H}_{\mathrm{b}} / \mathrm{C}\right)_{\Upsilon}$ to the lower limit of thermoneutrality. 
Abstract of Dissertation Presented to the Graduate Council

of the University of Florida in Partial Fulfillment of

the Requirements for the Degree of Doctor of Philosophy

THE INELUENCE OF DISTRIBUTION AND ECOLOGY

ON THE THERMOREGULATION OF SMALL BIRDS

\author{
By \\ Charles Gerald Yarbrough \\ June, 1970
}

Chairman: Davia W. Johnston

Major Department: Zoology

Data from the present study and the literature show that the energetics of thermoregulation in small birds are accurately described by the Newtonian model of heat loss. The level of body temperature is closely correlated with basa? metabolic rate, thermal conductance, and body weight.

Tropical and desert birds generally have lower relative thermoregulatory quotients than expected (less than 1.0) on the basis of weight alone, and cold-climate species have high relative ratios. The relative ratio is a measure of the impact of ecology and climate on thermoregulatory capacity. Larger body weight can compensate for a low relative ratio, within jimits.

Bird data now available indicate that ecology, particularly food rabit, limits the distribution of birds outside the tropics and deserts, and that thermoregulatory 
parameters are acapted primarily to climate.

Studies of the energetics of $\mathrm{T}_{\mathrm{b}}$ regulation in nondesert iropical birds should give information as to the impact of ecology on this process, in that the climatic variable would be absent. 


\section{INTRODUCTION}

Thermal homeostasis and its energetic cost for endothermic animals have been extensively documented over the last 20 years. The Newtonian model of heat loss has been used as a unifying method of looking at some of the parameters of body temperature regulation. This relationship is usually stated as:

$$
\mathrm{dQ}_{\mathrm{L}} / \mathrm{dt}=\mathrm{C}\left(\mathrm{T}_{\mathrm{b}}-\mathrm{T}_{\mathrm{a}}\right)
$$

in which $\left(\mathrm{dQ}_{\mathrm{L}} / \mathrm{dt}\right)^{1}$ is the rate of heat loss, $\mathrm{T}_{\mathrm{b}}$ is body temperature, $\mathrm{T}_{\mathrm{a}}$ is the ambient temperature, and $\mathrm{C}$ is $\mathrm{a}$ proportionality factor known as thermal conductance. In thermoneutral or cooler ambient temperatures with no radiant energy source, it is obvious that $\left(d Q_{L} / d t\right)=$ rate of heat gain = metabolic rate $(M)$, if the animal is going to hold $\mathrm{T}_{\mathrm{b}}$ constant.

The zone of thermoneutrality for an endotherm is a range of $\mathrm{T}_{\mathrm{a}}$ over which $\mathrm{i}$ is constant and independent of $\mathrm{T}_{\mathrm{a}}$. If the animal is postabsorptive and quiescent, is equal to the basal metabolic rate $\left(\mathbb{M}_{b}\right)$ over this $T_{a}$ range. In this zone, heat balance is maintained by physically changing the conductance (e.g., fluffing or compressing the fur or feathers). Ambient temperatures below the thermo-

1 All symbols and expressions used in this paper are defined in Appendix A. 
neutral zone result in an increase in $M$, and the proportionality of this increase to the $\left(\mathrm{T}_{\mathrm{b}}-\mathrm{T}_{\mathrm{a}}\right)$ difference is a measure of $\mathrm{C}$. $\mathrm{T}_{\mathrm{a}}$ above thermoneutrality also result in increased M values, mainly because of muscular activity associated with panting and the van't Hoff effect on chemical heat production.

The energetics of mammalian $\mathrm{T}_{\mathrm{b}}$ regulation are better understood than those of birds. This stems from a number of reasons. Interest in avian thermoregulatory studies developed rather slowly, major stimuli being the series of papers by Scholander et al. (1950a, b, c) and studies of hummingloira metabolism by Pearson (1950). Avian species studied subsequently have not been as representative of the diversity in size, ecology, and distribution within the class as has been the case with mammals. In many instances, avian thermoregulatory studies have been incomplete because of the absence of precise measurements of the $\mathrm{T}_{\mathrm{b}}$ that is being regulated. Failure to report precise $\mathrm{T}_{\mathrm{b}}$ values for $M$ measurements often will introduce bias into calculations, and greatly reduce the further usefulness of the data.

The review of energetics and thermoregulation in birds by King and Farner (1961) has been of considerable value in giving Airection and perspective to this area of investigation. From the data then available, they derived an equation relating $M_{b}$ and body weight (W) in small birds (ca. 100 grams or less) and another equation for birds larger than 100 
grams. A standard equation relating conductance and $\mathrm{W}$ in birds is given by Lasiewski et al. (1967). Both of these equations will be discussed later.

A few attempts have been made at analyzing thermoregulation in terms of environmental demands, especially heat stress and evaporative cooling (e.g., Bartholomew et al., 1962; Calder, 1964; Dawson and Fisher, 1969; Ligon, $1969)$.

Scholander et al. (1950c) have placed the emphasis on insulation for thermoregulatory adaptation to low $\mathrm{T}_{\mathrm{a}}$. It is now apparent (for example, Hart, 1957) that the basal metabolic rate may also be adaptive. The adaptive nature of body temperature is equivocal.

From Newton's heat loss relationship, one could anticipate that in response to environmental stress (thermal and/or nutritional) an animal could (l) behaviorally or physiologically alter the $\left(\mathrm{T}_{\mathrm{b}}-\mathrm{T}_{\mathrm{a}}\right)$ difference, physically change its conductance, (3) chemically alter the rate of metabolism, or (4) achieve some suitable combiration of these features. The behavior of these parameters in relation to ecology and climate has been investigated in some mammals, particularly by McNab (1966b, 1969, 1970; McNab and Morrison, 1963).

The relationships among thermal and ecological factors involved in thermoregulation have not been critically studied in birds. Ecological and distributional correlations have been made with differences in $M_{b}$ and/or $C$ in only a few species (wallgren, 1954; Lasiewski and Dawson, 
1964; Joinson, 1968; Ligon, 1968). No attempt has been made to synthesize into a rational whole the relationships that may be of general application in birds. McNab (1966a) has suggested that $\mathrm{T}_{\mathrm{b}}$ in birds is determined by the ratio of $\mathrm{M}_{\mathrm{b}}: \mathrm{C}$, much the same as in mammals. He has also indicated (1969) that in neotropical bats the $\left(\mathrm{M}_{\mathrm{b}} / \mathrm{C}\right)_{\mathrm{O}}$ ratio, and thus thermoregulatory capacity, is ecologically determined, especially by the reliability of the food supply.

The present study compares the behavior of thermoregulatory parameters in response to thermoneutral or cooler $\mathrm{m}_{\mathrm{a}}$ for representatives of three avian families having different food habits. It was suspected, in view of the great mobility of temperate zone birds, that food habit might be more influential on distribution than on the thermoregulatory capacity. These studies on sparrows, warblers, and flycatchers were undertaken to explore this possibility. Representative data on thermoregulation from the literature have been incorporated in the analysis of physical and ecological correlates of general application in birds. 
All specimens used in this study were caught in mist nets. Most of the flycatchers were obtained in the coastal plain of North Carolina, the Harris' Sparrows $^{l}$ near Lawrence, Kansas, and the Black-throated Trogon along the Rio Negro near the junction with the Rio Branco in the state of Amazonas, Brazil. All other birds were caught in the vicinity of Gainesville, Florida, during 1968-59. The time of year in which measurements were made for each species is indicated in Appendix B.

The Harris' Sparrows were maintained in captivity, but all other specimens were caught during the day (usually afternoon) and were used for metabolic determinations the same night. Small birds were fasted for at least five hours and large birds six to seven hours before data collection was begun. Only data obtained between 2100 and 0500 hours were included in the study. Specimens were kept in complete Carkness during the study interval. All data from birds suspected of being in Zugunruhe were excluded.

Hetabolic rate was measured at three different ambient temperatures: $10^{\circ}, 20^{\circ}$, and $30.5^{\circ} \mathrm{C}$, or as otherwise indicated in a few cases. An open flow system was employed, and

1 Scientific names of all birds used appear in Appendix B. 
air flow rates were sufficient to maintain a concentration of at least 20 per cent oxygen in the metabolism chamber. This chamber had a volume of one gallon, and was immersed in a large, constant-temperature water iath. When a temperature change was desired, the chamber was switched to another water bath preset at the desired temperature. An interval of about two hours was allowed for the bird to adjust to tine new temperature before data were used.

The partial pressure of oxygen in the air stream was measured by a Beckman G-2 Paramagnetic Oxygen Analyzer after carbon dioxide and water had been removed. Oxygen concentrations were recorded on a Honeywell strip chart recorder.

When a satisfactory metabolic reading was attained, the bird was quickiy removed from the chamber and the proventricular body temperature was measured by a YSI telethermometer. The bird could be removed and its $\mathrm{T}_{\mathrm{b}}$ measured in less than one minute. Thus, each metabolic value has a corresponding $\mathrm{T}_{\mathrm{b}}$ reading. 


\section{RESULTS}

Data obtained in this study from 29 species of small birds are shown in Figures $1-14$ and are summarized for each species in Table 1. These figures depict, species by species, the effects of different ambient temperatures on body temperature and metabolic rate (as measured by oxygen consumption). Metabolic measurements made within the zone of thermoneutrality are basal levels $\left(\mathrm{M}_{\mathrm{b}}\right)$. At $\mathrm{T}_{\mathrm{a}}$ below the lower limit of this zone, oxygen consumption increases. The slope of a line describing this $M$ increase with declining $\mathrm{T}_{\mathrm{a}}$ is considered to be the thermal conductance of the species. General patterns of these responses are indicated later in this section.

For all species studied, the data indicate that $30.5^{\circ} \mathrm{C}$ is well within the zone of thermoneutrality. This is supported by the fact that most of the metabolic records obtained at this $T_{a}$ were quite smooth, whereas records taken at $10^{\circ}$ or $20^{\circ} \mathrm{C}$ usually showed oscillations between maximal and minimal values, presumably due to periodic bursts of shivering or other muscular activity. Thus, metabolic values taken at $30.5^{\circ} \mathrm{C}$ are probably basal rates, and represent the lowest constant level maintained for 15 minutes. For metabolic measurements below thermoneutrality, the repeatable minima are used. This procedure minimizes both $\mathrm{H}_{b}$ and $C$. 
Fig. 1. Responses of body temperature and oxygen consumption to ambient temperature in spizelza passerina and zonotrichia albicolzis. The lower part of the graph shows the relationship between oxygen consumption $\left(\mathrm{N}_{i}\right)$ and ambient temperature $\left(T_{a}\right)$. Horizontal lines indicate the mean basal metabolic rate for each species. The absolute value of the slope of each line in the lower part of the graph represents the mean thermal conductance for each species. The upper portion of the graph gives the body temperatures $\left(T_{b}\right)$ corresponding to the $M$ values below. The slanted line in the upper part is a reference which equates the temperature axes.

Fig. 2. Responses of body temperature and oxygen consumption to ambient temperature in Passercuius sandwichensis and Ammodramus savannarum. See the legend of Fig. I for explanation. 


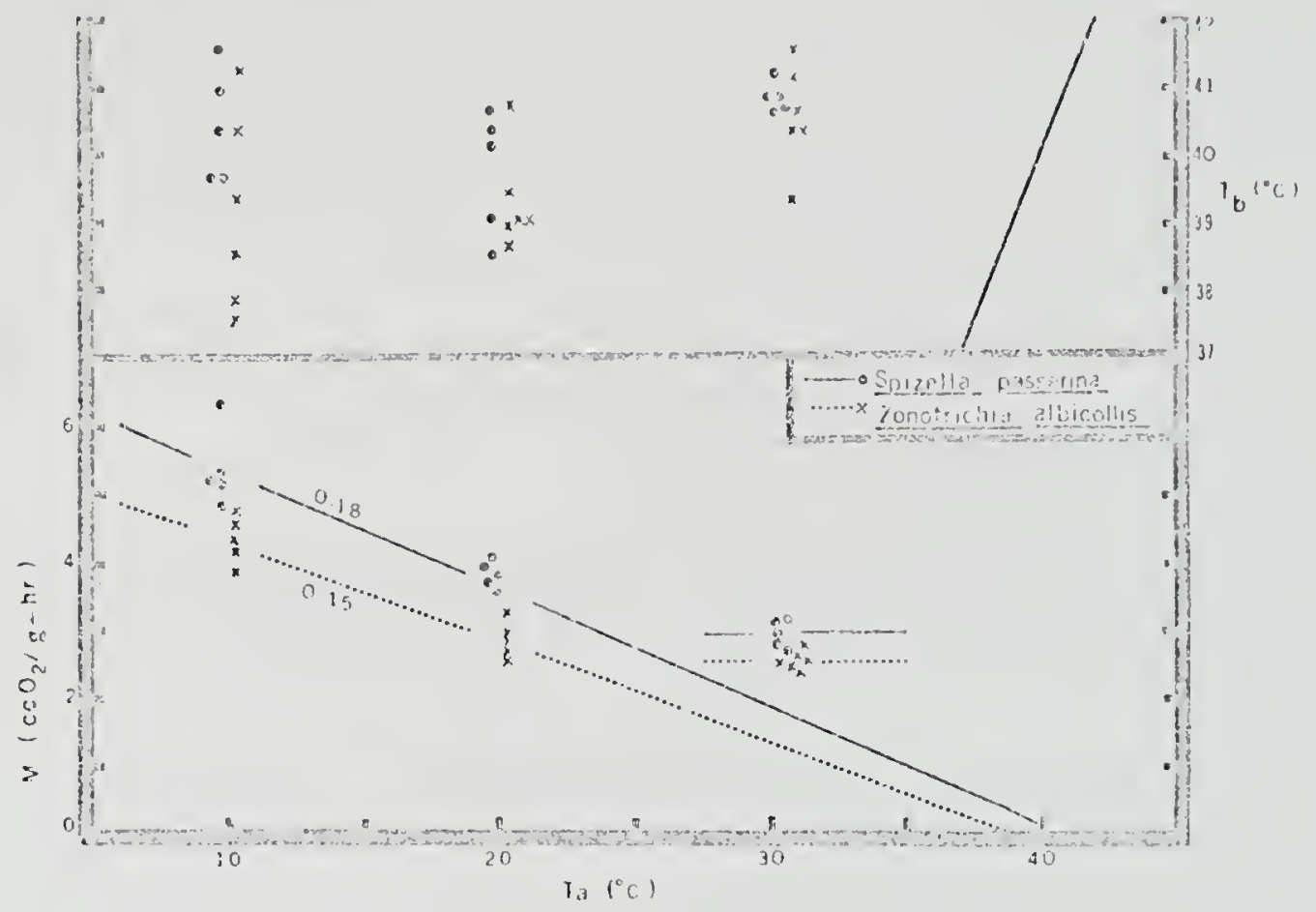

9

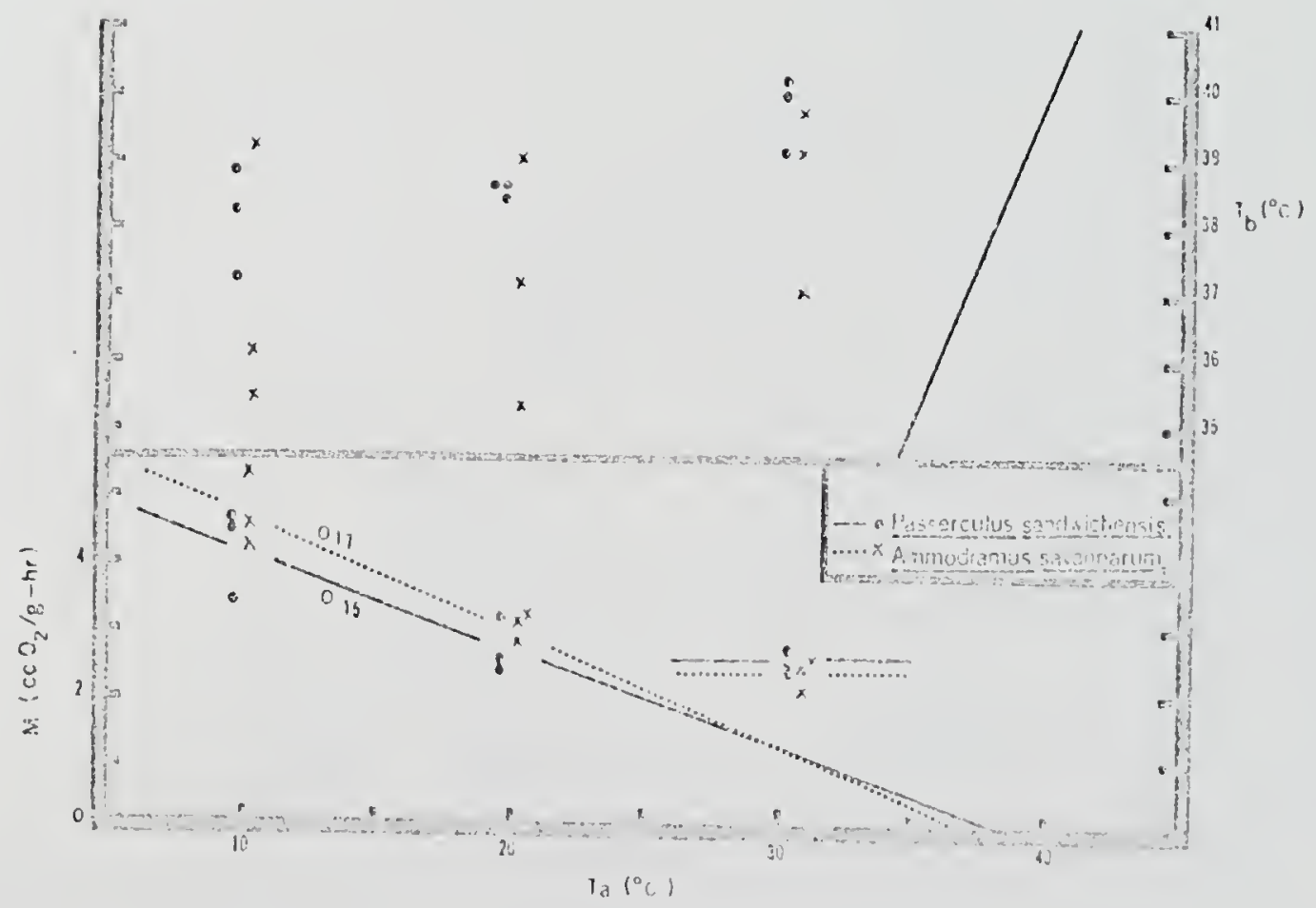


Fig. 3. Responses of body temperature and oxygen consumption to ambient temperature in Melospiza melodia and Melospiza georgiana. See the legend of Fig. I for explanation.

Fig. 4. Responses of body temperature and oxygen consumption to ambient temperature in pooecetes gramineus and Passerella iliaca. See the legend of Fig. I for explanation. 
II
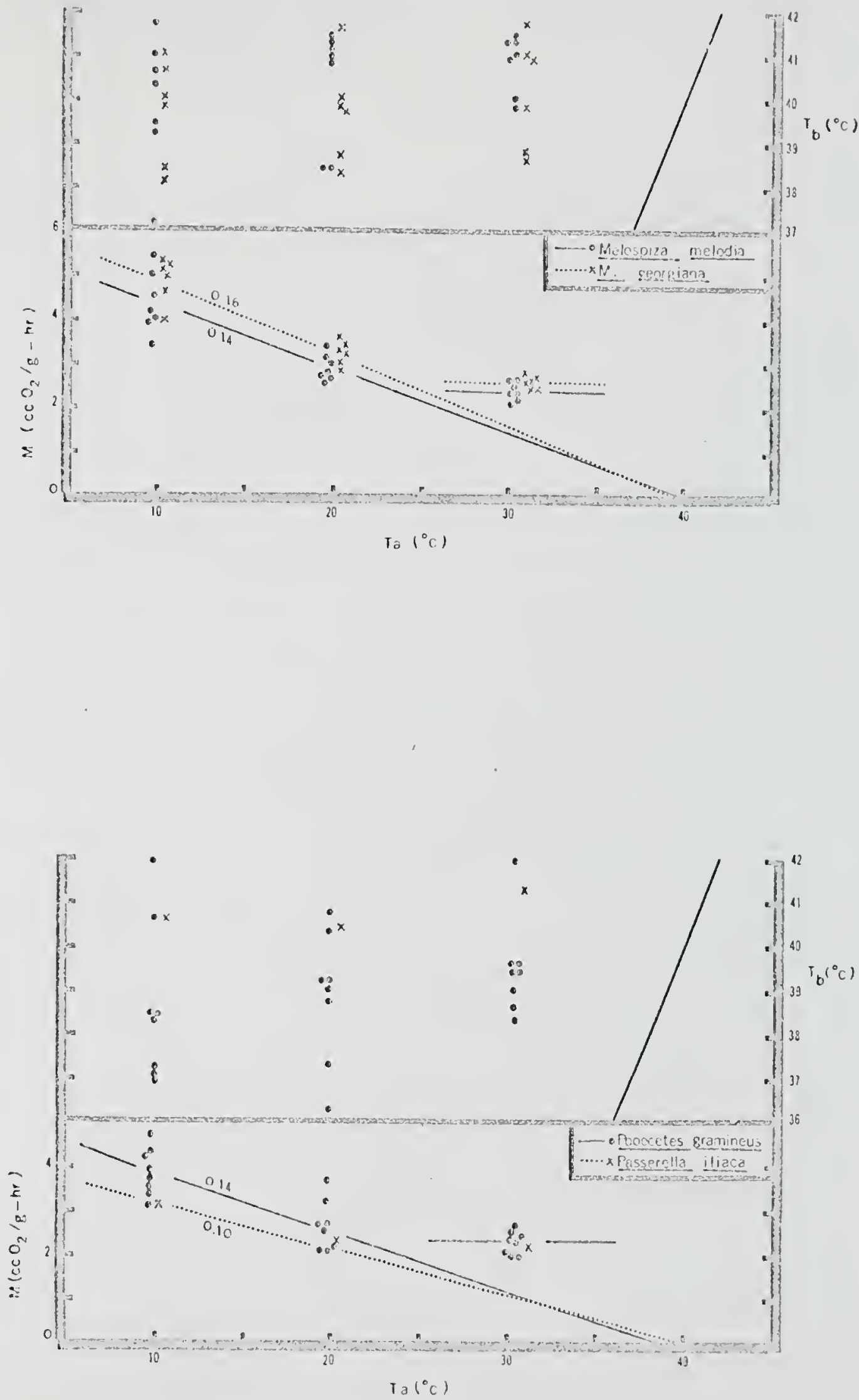
Fig. 5. Responses of body temperature and oxygen consumption to ambient temperature in zonotrichia querula and Zonotrichia Zeucophrys. See the legend of Fig. I for explanation.

Fig. 6. Responses of body temerature and oxygen consumption to ambient temperature in Parula americana and Vermivora pinus. See the legend of Fig. I for explanation. 

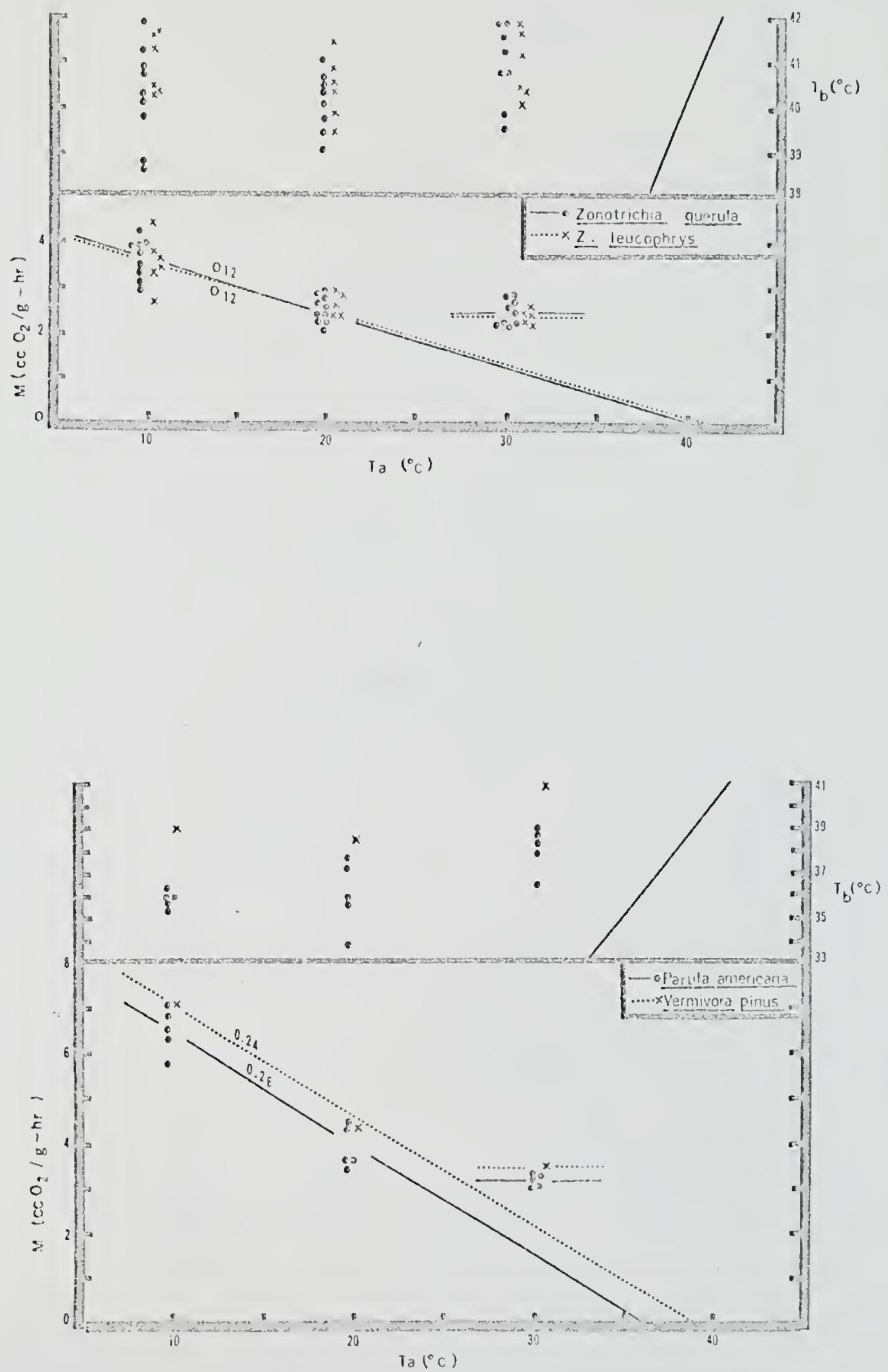
Fig. 7. Responses of body temperature and oxygen consumption to ambient temperature in Dendroica pinus, Vermivora celata, and Mniotilta varia. See the legend of Fig. I for explanation.

Fig. 8. Responses of body temperature and oxygen consumption to ambient temperature in Dendroica coronata and Protonotaria citrea. See the legend of Fig. 1 for explanation. 
15
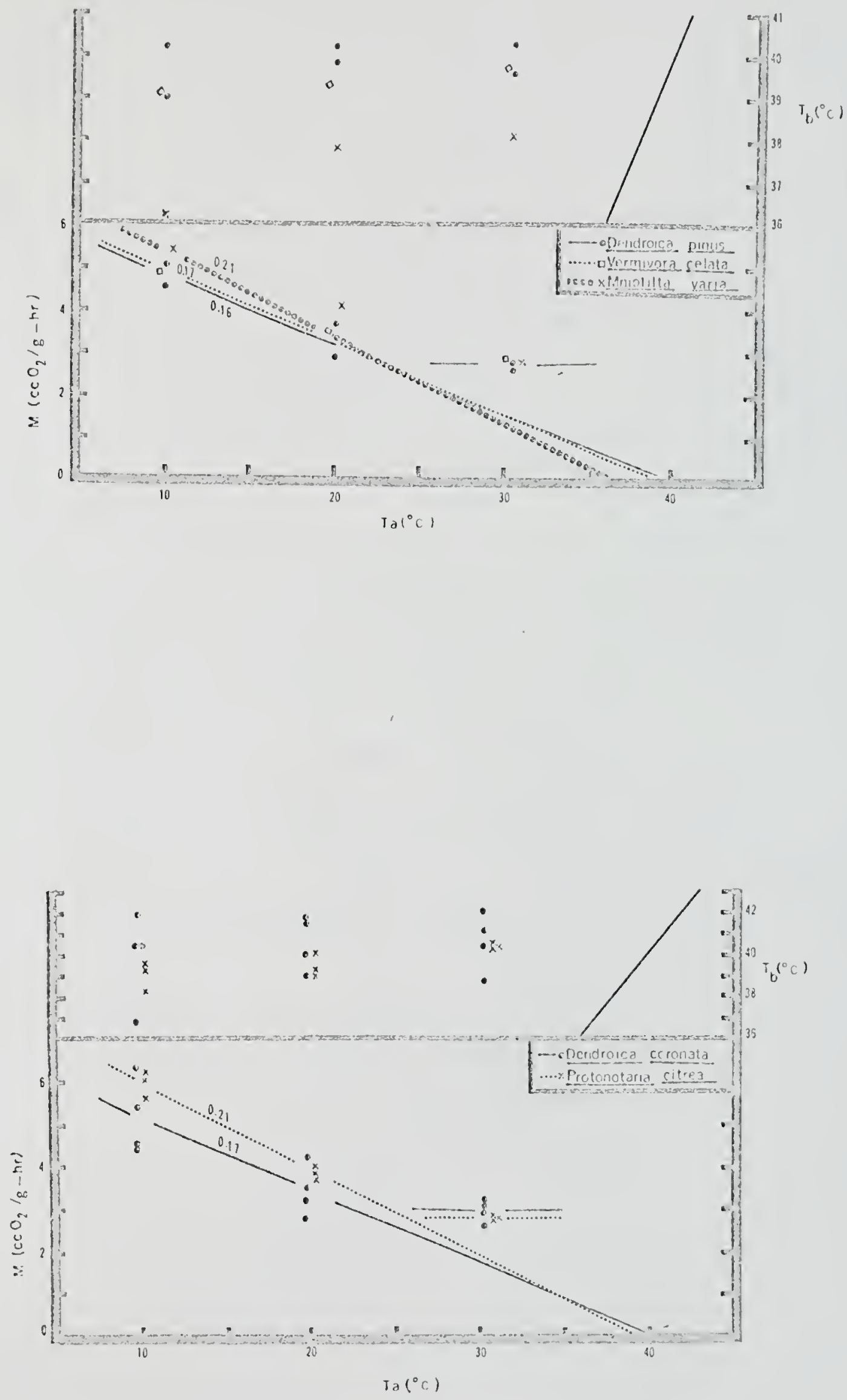
Fig. 9. Responses of body temperature and oxygen consumption to ambient temperature in Wilsonia citrina and Dendroica dominica. See the legend of Fig. 1 for explanation.

Fig. 10. Responses of body temperature and oxygen consumption to ambient temperature in seiurus noveboracensis and seiurus aurocapizzus. See the legend of Fig. 1 for explanation. 


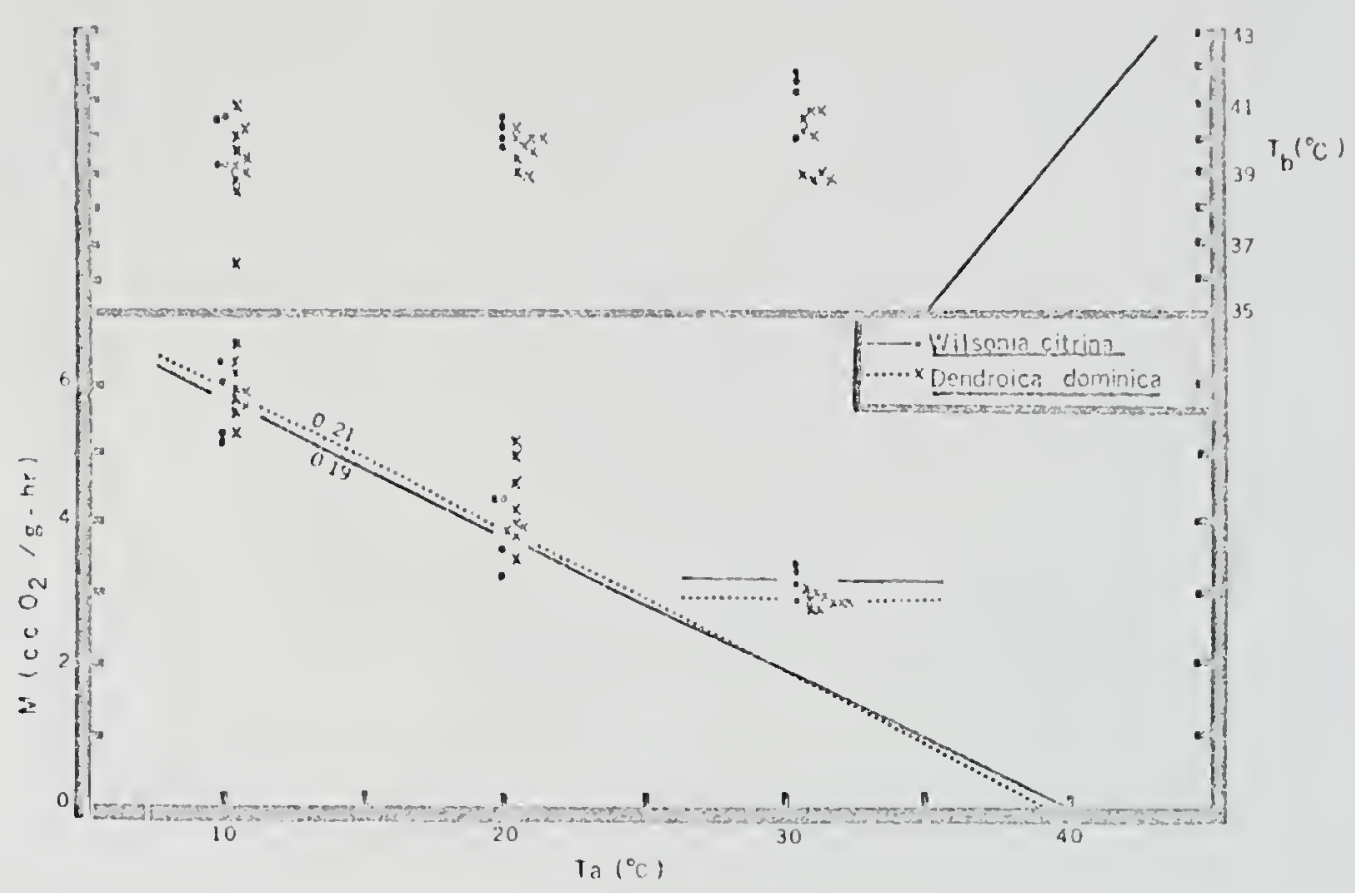

17

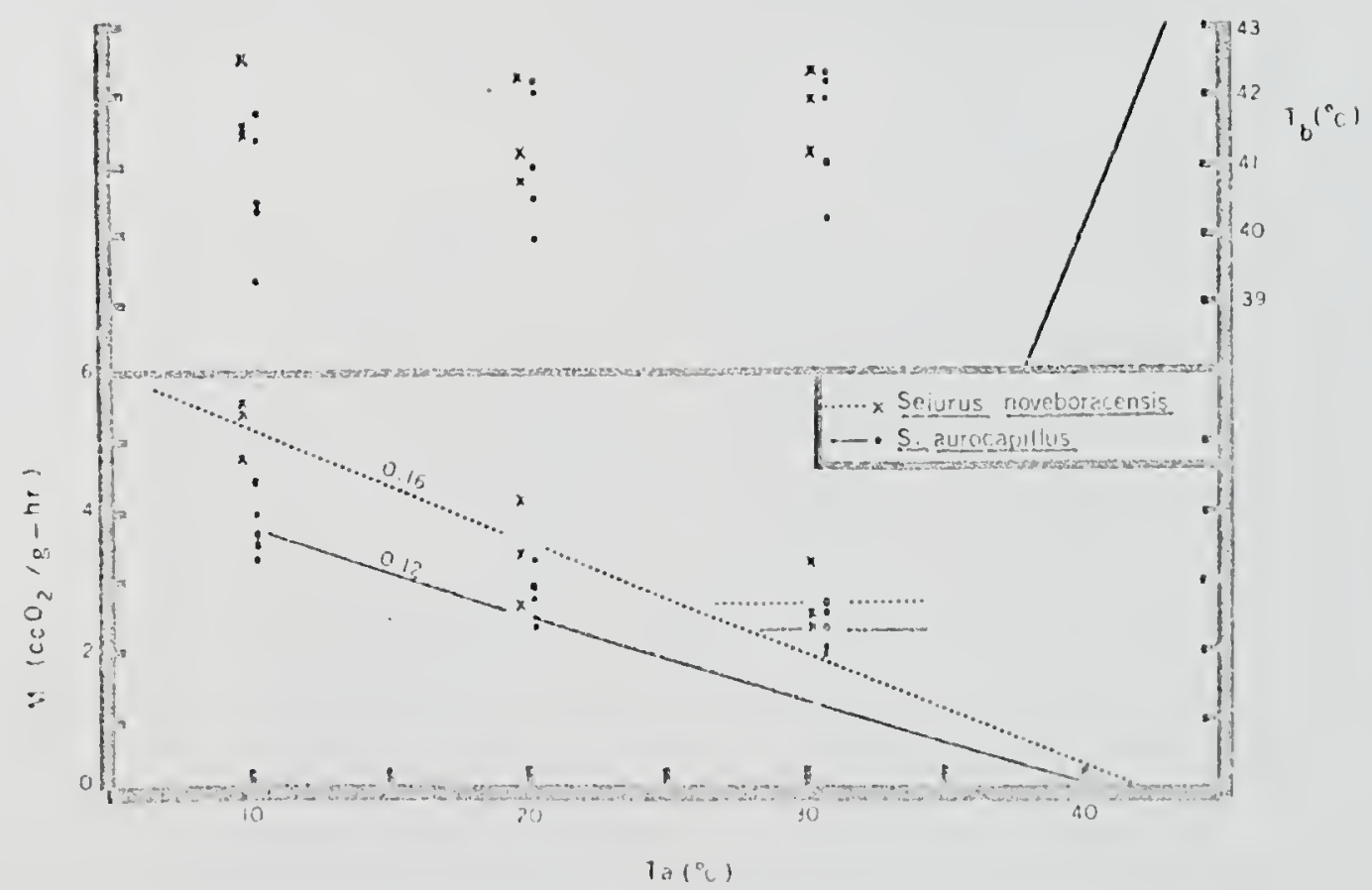


Fig. 11. Responses of body temperature and oxygen consumption to ambient temperature in Denaroica palmarum and Trogon rufus. See the legend of Fig. J. for explanation.

Fig. 12. Responses of body temperature and oxygen consumption to ambient temperature in sayornis phoebe and Geothlypis trichas. See the legend of Fig. I for explanation. 

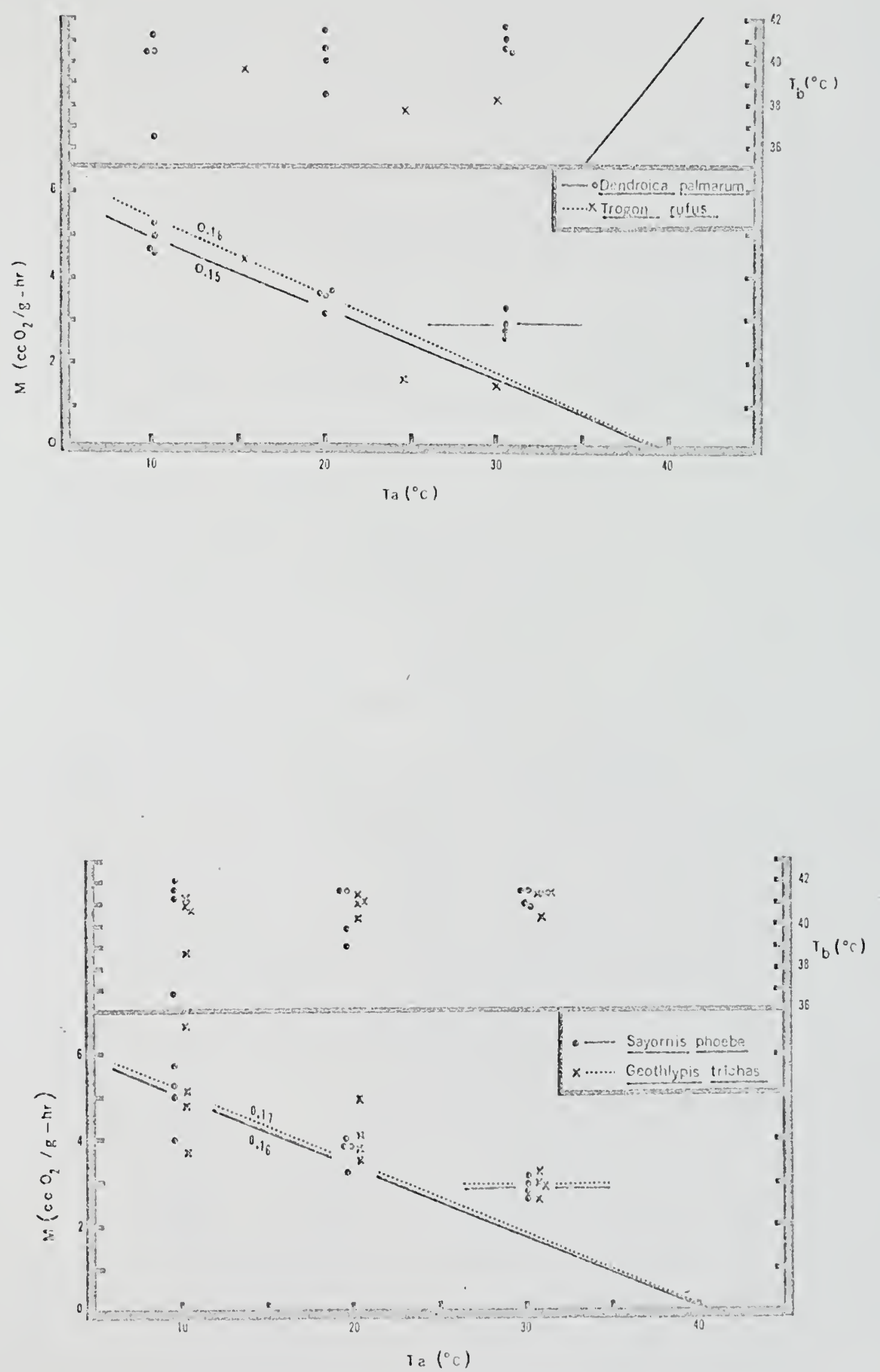
Fig. 13. Responses of body temperature and oxygen consumption to ambient temperature in Empidonax virescens and contopus virens. See the legend of Fig. I for explanation.

Fig. 14. Responses of body temperature and oxygen consumption to ambient temperature in Myiarchus crinitus and Tyrannus tyrannus. See the legend of Fig. I for explanation. 

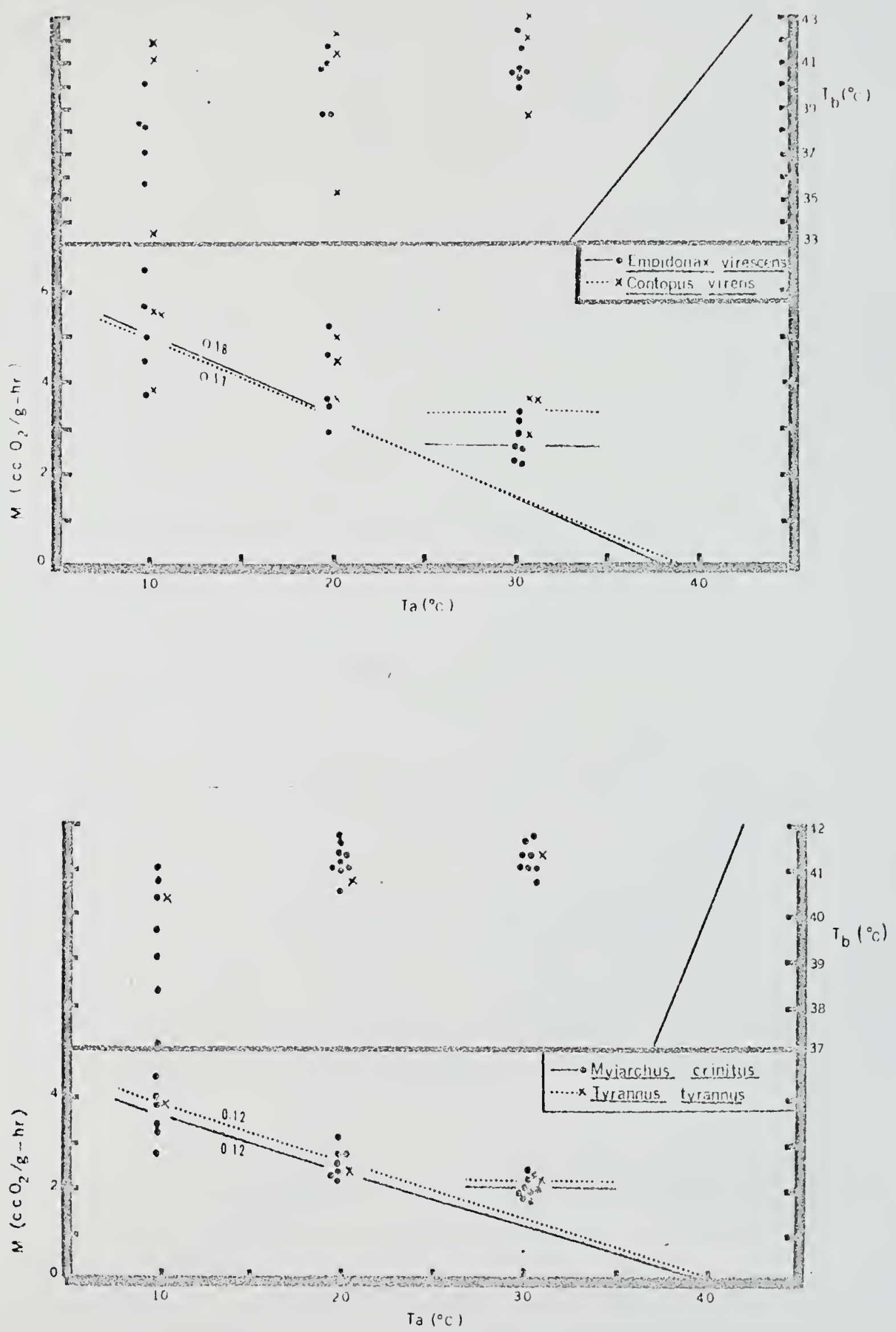


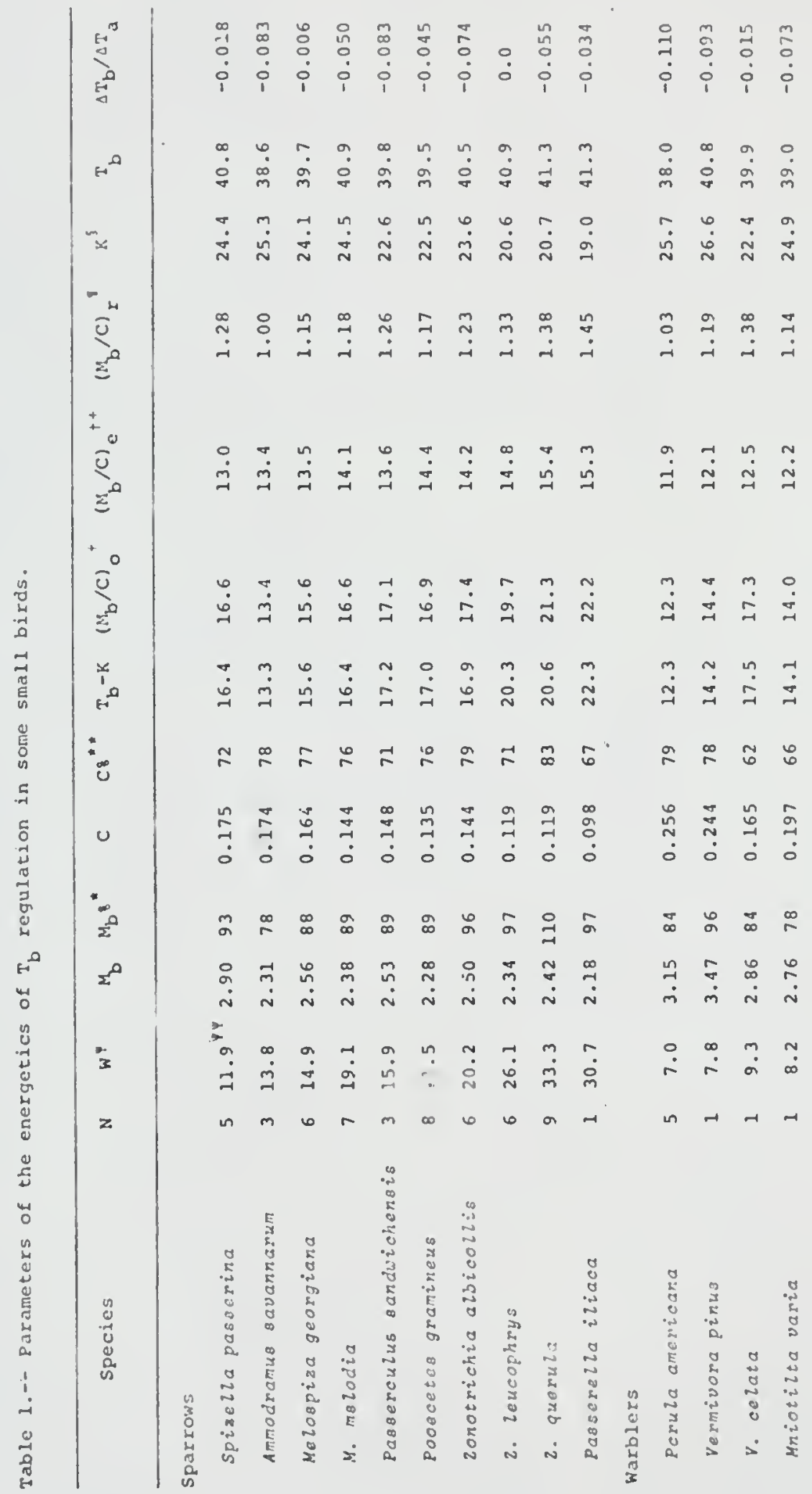




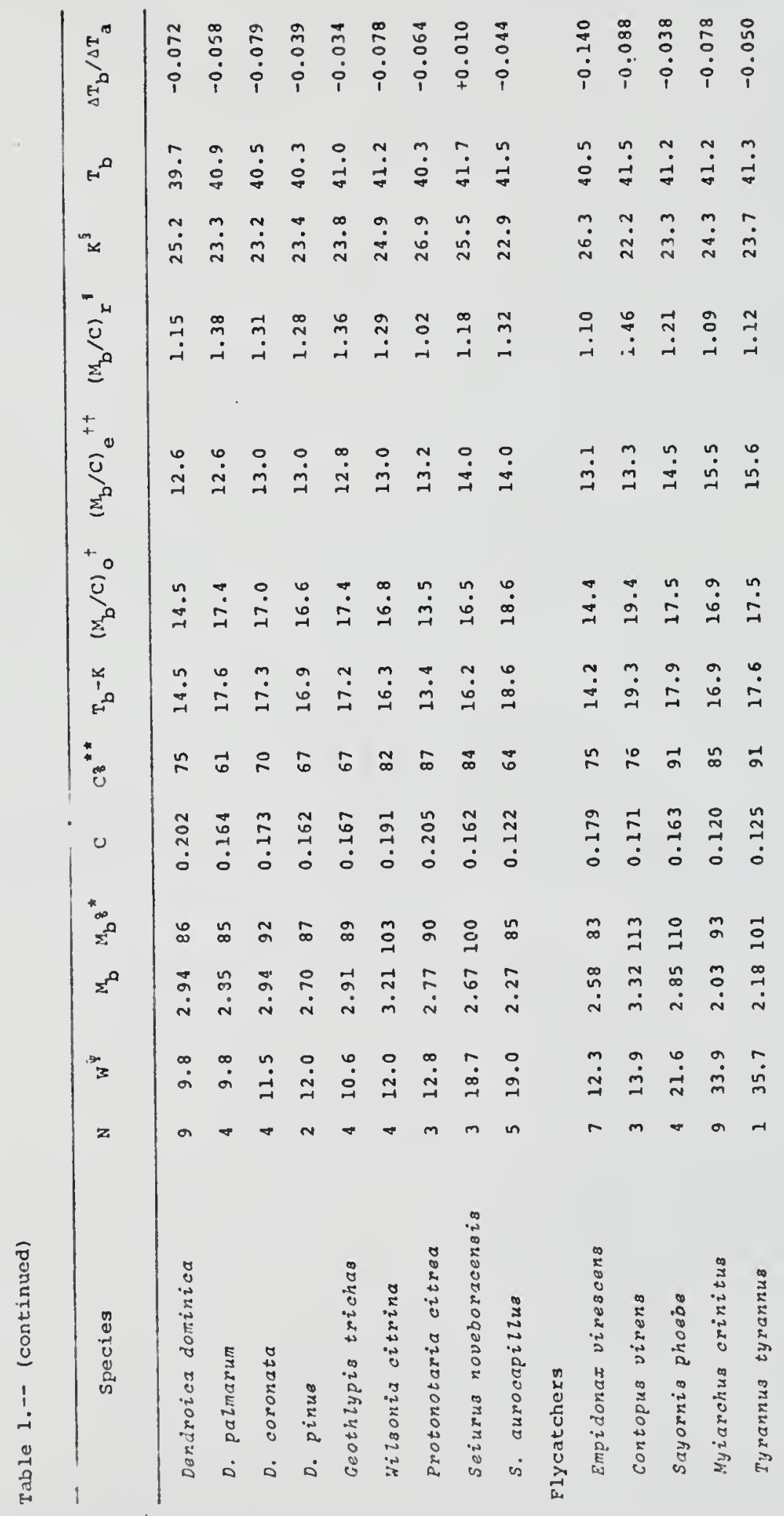




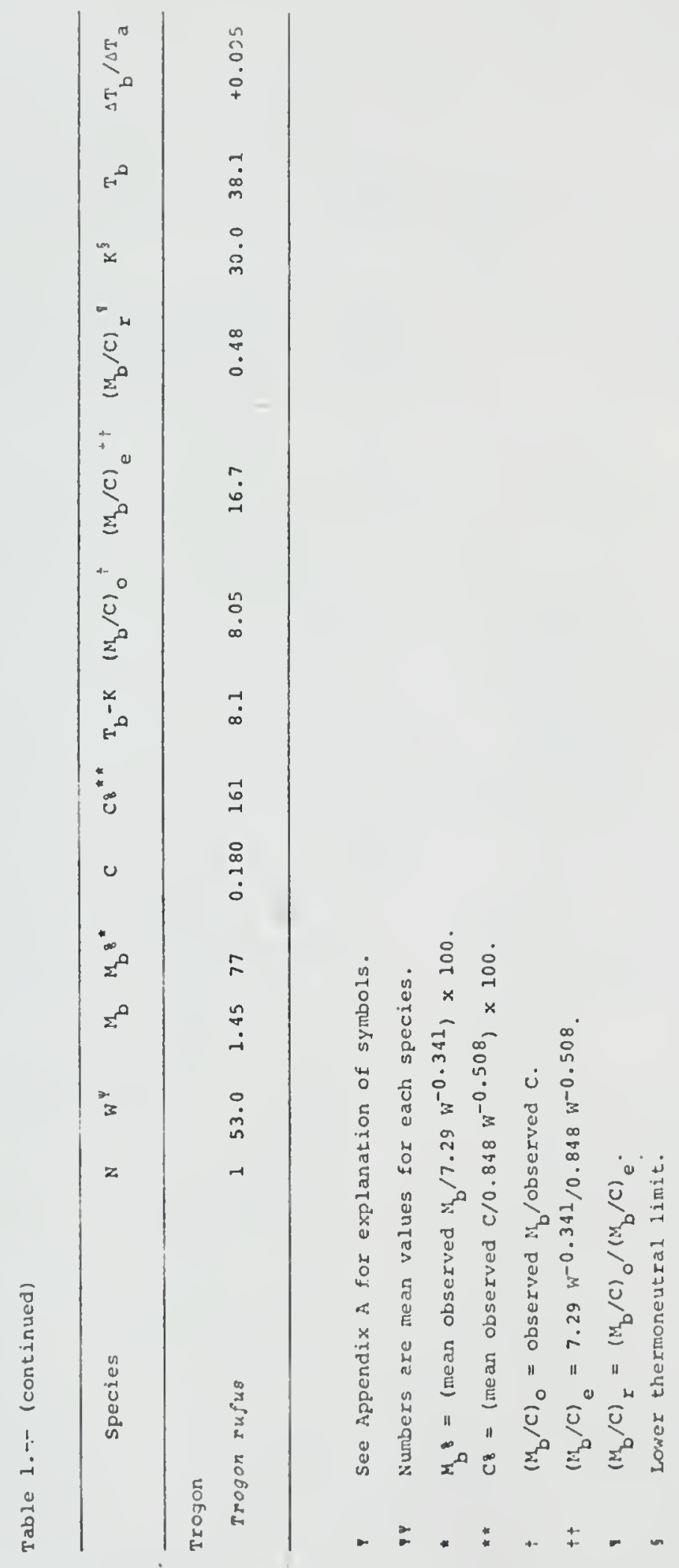


The mean $\mathrm{M}_{\mathrm{b}}$ for ten species of sparrows is 92.6 per cent of that expected from the equation of King and Farner (1961) for small birds, and $C$ is 75.0 per cent of the value expected from the equation of Lasiewski et al. (1967) (Figs. $1-5,15,16$, and Table 1). Of the families studied here, the sparrows have the most northern wintering distribution, and contrast with the tropical Black-throated Irogon, which has $\mathrm{a} \mathrm{M}_{\mathrm{b}}$ only 77 per cent of that expected and a very high C (161 per cent) (Figs. 11, 15, 16, and Table 1).

The mean $\mathrm{M}_{\mathrm{b}}$ for all warblers is 89.2 per cent of that expected and $\mathrm{C}$ is only 72.4 per cent of the expected value (Figs. 6-12, 15, 16, and Table 1). Eight species wintering as far north as the southeastern United states liave lower $\mathrm{M}_{\mathrm{b}}$ and $\mathrm{C}$ values ( 85.8 and 66.5 per cent) than five species wintering farther south (94.6 and 82.0 per cent). These values indicate a considerable reduction in energy expenditure.

The five species of flycatchers have a collective $\mathrm{M}_{\mathrm{b}}$ which is 100 per cent of that expected. C is 83.6 per cent of that expected, and the Acadian and Wood Pewee have a lower C (75.5 per cent) relative to that expected than the larger flycatchers (89.0 per cent) (Figs. 12-14, 15, 16, and Table 1).

Each metabolic datum is accompanied by a $\mathrm{T}_{\mathrm{b}}$ value (Figs. 1 - 14). The mean $\mathrm{T}_{\mathrm{b}}$ for sparrows and warblers in thermoneutralicy was identical $\left(40.3^{\circ} \mathrm{C}\right)$, but was less than tinat of flycatchers $\left(41.1^{\circ} \mathrm{C}\right.$ ). Very small birds ( 10 grams) usually have $\mathrm{T}_{\mathrm{b}}$ that are lower and more sensitive to cool Ta than those of larger species. 
Fig. 15. The relation of basal metabolic rate to body weight in some small birds. The line is a plot of the King-Farner (1961) equation for small birds $\left(\log \mathrm{M}_{b}=\log 7.29-0.341 \log \mathrm{W}\right)$. Each point is the mean value for a species.

Fig. 16. The relation of thermal conductarce to body weight in some small birds. The line is a plot of the equation of Lasiewski et al. (1967) $(\log C=\log 0.848-0.508 \log$ i $) . \quad$ Each point is the mean for a species. 
27
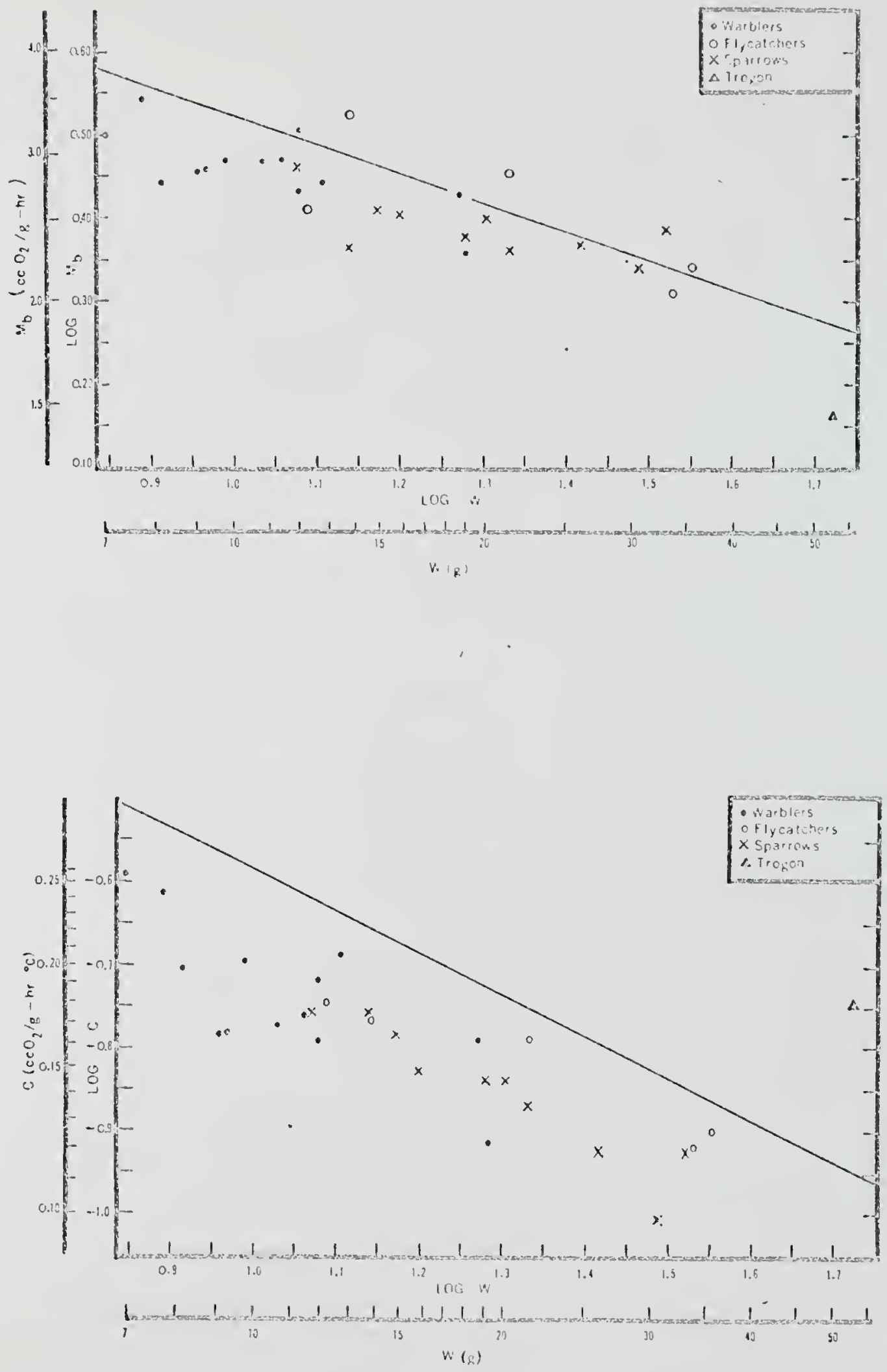


\section{DISCUSSION}

\section{Heat Loss and Heat Gain}

Heat loss in animals is an extremely complex process. The factor $\mathrm{C}$ conceals a multiplicity of problems concerning heat loss by radiation, conduction, convection, and evaporation of water. The effective body surface area may be temporally varied, peripheral and appendicular blood circulation is subject to alteration, and the temperature of the body surface from which heat is lost may be different than that measured in the core. Some of these problems have been discussed in detail by Burton (1934), Scholander et $a$ r. (1950a, b, c), Kleiber (1961), Bartholomew and Tucker (1964), and Miciab (1970).

It would be desirable to have a rigorous experimental capability such that the physical parameters could be measured which are necessary for using models such as Fourier's law of heat flow. The ability to apportion properly the responsibility for heat loss among radiation, convection, and conduction as well as evaporation is also a worthy aspiration. However, as indicated in the previous paragraph, there are a number of reasons why this is impractical, if not impossible, at present. It is important that we begin to measure quantitativoly tire partitioning of heat loss by birds. This partitioning is probably highly adaptive. 
Knowledge of trends of performance by each avenue of heat loss would allow us to understand the thermal and ecological interrelationships of individual species. The recent studies by Hamilton and Heppnex (1967) and Heppner (1970) on radiative energy exchange and its effect on the heat budgets of dark and light birds are steps in this direction. However, the details of the partitioning of heat loss are overlaid by more general thermo-ecologic patterns. In the final analysis, it is the total rate of heat loss that must be balanced by heat production. It is exactly at this point that the Newtonian model is useful. Its employment simply ignores the various reasons for heat loss, and considers the totality of heat lost as a single parameter.

This approach, although simplistic, allows examination of the relationship of metabolic heat gain (M), and total heat loss $C\left(T_{b}-T_{a}\right)$, to biological and distributional characteristics of a species, such as ecology and climate. It will be seen that the available data fit this simple approximaticn remarkably well. As long as the physical limitations of this concept are understood, I believe that it can be of considerable heuristic value in a biological sense.

The Newtonian model was originally used to describe the cooling of a body. Since a decline in temperature does not generally occur in homoiotherms, it is sometimes argued that this law is not applicable to such systems. The argument becomes rhetorical when the cooling expression is rewritten as a heat loss statement using the specific heat (c) and body weight (w) : 


$$
\begin{aligned}
& \mathrm{dT}_{\mathrm{b}} / \mathrm{dt}=\mathrm{k}\left(\mathrm{T}_{\mathrm{b}}-\mathrm{T}_{\mathrm{a}}\right) \\
& \mathrm{dT}_{\mathrm{b}} / \mathrm{dt}=\mathrm{dQ} / \mathrm{dt} \cdot 1 / \mathrm{CW} \\
& \therefore \mathrm{dQ} / \mathrm{dt} \cdot 1 / \mathrm{CW}=\mathrm{k}\left(\mathrm{T}_{\mathrm{b}}-\mathrm{T}_{\mathrm{a}}\right) \text { and } \\
& \mathrm{dQ} / \mathrm{dt}=\mathrm{kCW}\left(\mathrm{T}_{\mathrm{b}}-\mathrm{T}_{\mathrm{a}}\right) \text { or } \\
& \mathrm{dQ} / \mathrm{dt}=\mathrm{C}\left(\mathrm{T}_{\mathrm{b}}-\mathrm{T}_{\mathrm{a}}\right)
\end{aligned}
$$

where $\mathrm{C}$ is a composite proportionality factor commonly known as thermal conductance.

\section{Metabolism}

of the species of birds used in this study, only a few sparrows have been subjected to metabolic examination by other investigators. Table 1 shows that sparrows larger than 20 grams have $\mathbb{M}_{b}$ almost exactly as predicted from w by the King-Farner equation, except for the Vesper, which also has a lower $\mathrm{T}_{\mathrm{b}}$. King's (1964) data on the whitecrowned sparrow agree with those obtained in this stuay. Rising's (1968) values for Harris' sparrow are much higher than expected (158 per cent) and were obtained by weighing $\mathrm{CO}_{2}$ produced. My data for the white-throated sparrow are similar to those of Hudson and Kimzey (1964). The values given by Lasiewski and Dawson (1967) for White-throated, Song, and Fox sparrows are considerably higher than those from this study. This may be due in part to differences in procedures of taking data from the strip charts. Figure 15 shows the position of my data in relation to the king-Farner curve for small birds.

It will be noted from table 1 that those sparrows with $M_{b}$ lower than expected usually also have lower $T_{b}$ than the other species. $M_{b}$ for most of the warblers are also 
somewhat lower than expected, particularly in species wintering in Florida or in very small species. This reduces energy expenditure considerably and may be very important for small insectivorous species wintering in cool climates. The reduction in $\mathrm{NI}_{\mathrm{b}}$ is made possible in such species by a comparatively better insulation. The two species of insectivores that winter in the southeastern U. S. and still maintain relatively high $\mathrm{M}_{\mathrm{b}}$ (Phoebe and Myrtle warbler) are known to depend heavily on berries for food auring winter (Bent, 1942, 1953; Yarbrough and Johnston, 1965).

The tropical and desert species in Table 2 have significantly reduced $\mathrm{H}_{\mathrm{b}}$ values in most cases. This may function mainly for reducing energetic demands (small hummingbirds) or for moderating the heat load and evaporative water loss (desert owls and goatsuckers). The species which appear to take exception to such strategies are either very small (Black-rumped Waxbill) or have exceptionally high $C$ values, even in view of their small body size (Paradise widowbird and Zebra Finch).

Lasiewski and Dawson (1967) have statistically separated standard metabolism curves of passerine and non-passerine birds. No biological rationale is evident for this decision. Indeed, there may be differences in $l_{b}$ between passerines and non-passerines; there probably are aifferent curves for penguirs and hummingbiras, auks and vultures, etc. Nonpasserines have been inadequately sampled over the size range from which most of the passerine data have been 


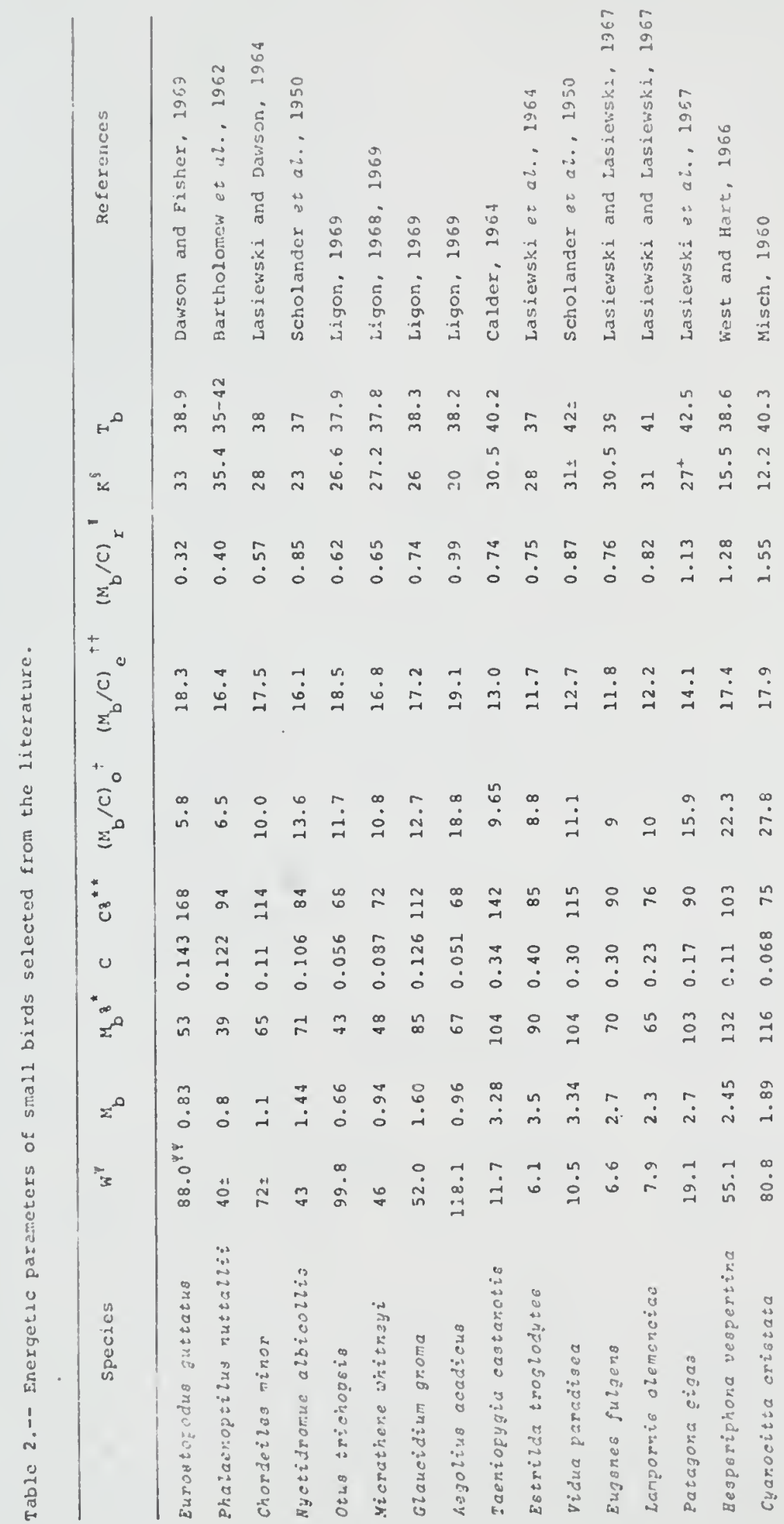




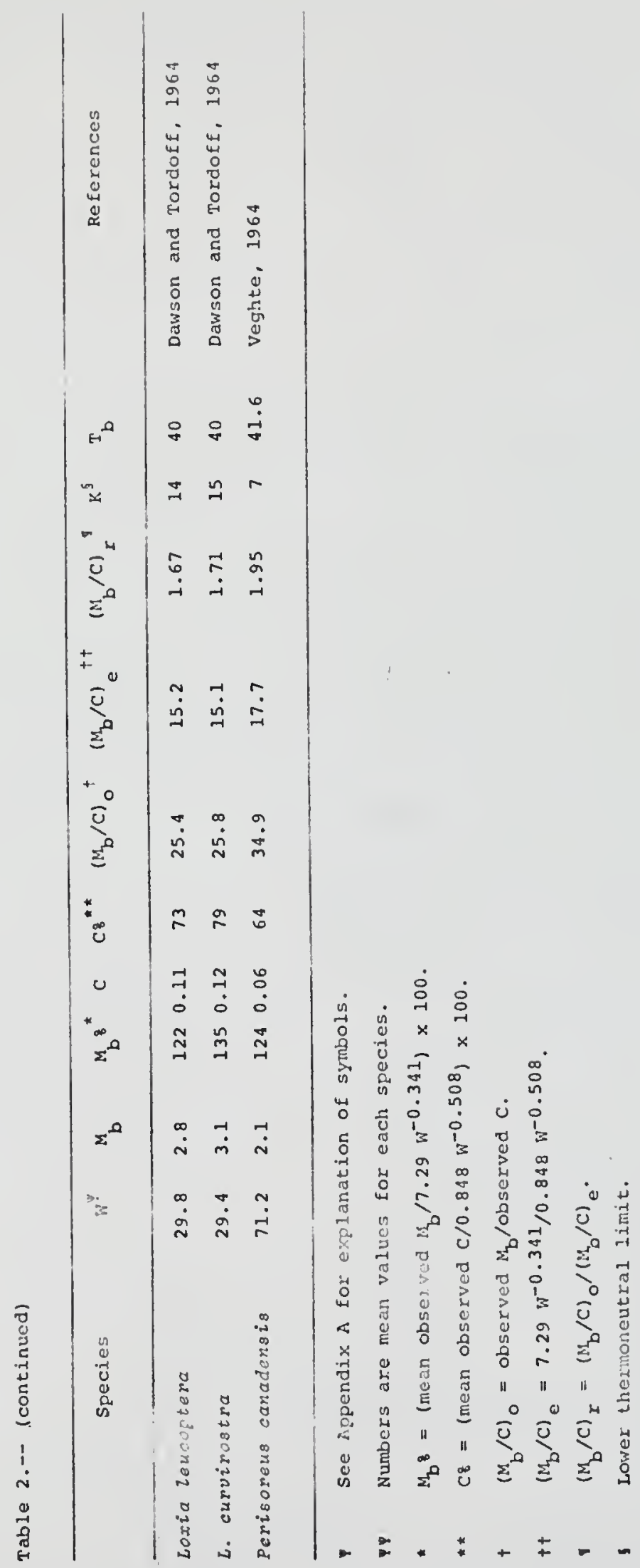


obtained. Perhaps even more important than body size are the ciinatic and ecological factors impinging on the biras in question. It might be expected that birds from the tropics or arid areas with great heat loads, soaring or gliding species, flightless birds, would have reduced metabolic heat production when compared to active foragers contending with cool, cold or variable $\mathrm{T}_{\mathrm{a}}$ in the absence of a capacity for torpor. llany more data are needed for passerine and non-passerine biras having similar aistributional histories, ecological characteristics, thermal environments, and body sizes before it can be said that physiological responses are determined by taxonomy at the ordinal level.

\section{Conductance}

As has been seen above, it is sometimes meaningless or even misleading to view heat gain without evaluating heat loss. I have already indicated that the procedure of datataking used here minimizes C. Data are available in the literature for only two of the species studied by me. King's (1964) C data on the White-crowned Sparrow are similar to those reported here, but Rising's (1968) C values for Harris' Sparrow are nearly double those in the current study. The mean $C$ for every species in the present study is lower than that predicted by the equation of Jasiewski et $a z$. (1967), except for the Biack-throated Trogon (Fig. 16). This completely troplcal species has a $c$ on a par with the Spotted Nightjar of Australian arid läds (Dawson and Fisher, 
It seems to be generally true that birds from the tropics or hot deserts have relatively high $\mathrm{C}$ values, and species that encounter cool weather have low $C$. However, there are some prominent exceptions to this generalization. Very small desert or tropical species, such as hummingbirds may not be able to tolerate increases in $\mathrm{C}$ (also compare the Black-rumped Waxbill with the larger Paradise Widowbird and zebra Finch). The smaller caprimulgids with more temperate wintering distributions (Poor-will and Pauraque) have relatively better insulation that the larger Nighthawk and spotted Nightjar that winter at lower latitudes.

The small nocturnal owls have good insulation (Table 2). Of course, the saw-whet is found in cold climates, and the Whiskered and Elf Owls are active during the cool desert nights. The only small owl in Table 2 with a relatively poor insulation is the Pygmy, which is largely diurnal in its activity and thus is exposed to the high $\mathrm{T}_{\mathrm{a}}$ of the southwestern U. S. and Mexico.

The importance of providing $\mathrm{T}_{b}$ measurements along with $M$ values is seen in the calculation of $C$. Some species of birds probably do not change abruptly from physical to chemical thermoregulation (Figs. 7, 9, 12, 13). Many species also experience a reduction in $\mathrm{T}_{\mathrm{b}}$ when $\mathrm{T}_{\mathrm{a}}$ is below the thermoneutral range. These effects are additive, and under such circumstances the slope of the regression line through the data points does not represent $C$. Minimal $C$ is the slope of 
a line connecting the mean $M$ value at a given $\mathrm{T}_{\mathrm{a}}$ below thermoneutrality with the corresponding mean $\mathrm{T}_{\mathrm{b}}$ at $\mathrm{M}=0$. The lower limit of thermoneutrality for purposes of calculation can be determined by translating this line to the right on the $\mathrm{x}$-axis to the point which is the $\mathrm{T}_{\mathrm{b}}$ measured at thermoneutral $\mathrm{T}_{\mathrm{a}}$.

\section{The Physical Mocel}

The relation of $M_{b}$ to $C$ for birds in the current study is compared to a line representing predicted values (Fig. 17). It has been stated previously that this relationship of heat gain (M) to the coefficient of heat loss (C) is a better expression of the thermoregulatory capacity of an animal than either parameter alone. Each of these factors can probably be modified by selection and/or acclimatization, but only with proper reference to the capacity of its companion factor and body size. For example, the response to an environmental alteration of $\mathrm{C}$ can be made only to the extent that body size is not limiting and that the animal can obtain an adequate fooa or water supply to operate at the new M level. All this must be aone within the framework that exists for maintenance and reproductive success. Therefore, the observed thermoregulatory guotient $\left(\mathrm{H}_{\mathrm{b}} / \mathrm{C}\right)_{0}$ is broadly composed of two components: $\left(\mathrm{H}_{\mathrm{b}} / \mathrm{C}\right)_{\mathrm{e}}$, the quotient expected of a "typical" bird of the specified $W$, and $\left(\mathrm{M}_{\mathrm{b}} / \mathrm{C}\right)_{\mathrm{r}}$, an index of that variation from "typical" that may be attributed to the adaptive impact of ecological and climatic demands. The modified heat loss equation can 
Fig. 17. The relation of the observed thermoregulatory quotient $\left(\mathrm{I}_{\mathrm{b}} / \mathrm{C}\right)$ o to body weight in some small

birds. The line is a plot of the quotient expected on the basis of weight from the equations of King and Farner (1961) and Lasiewski et al. (1967), $\log \left(\mathrm{M}_{\mathrm{b}} / \mathrm{C}\right)_{e}=\log 8.59+0.167 \log \mathrm{W}$.

Fig. 18. A plot showing the effect of body weight on thermoregulation data taken from birds used in this study and from the literature. Lines have slopes equal to $\left(\mathrm{M}_{\mathrm{b}} / \mathrm{C}\right) \mathrm{e}^{\text {. Data for the }}$ White-tailed Ptarmigan (Lagopus Zeucurus) are from Johnson (1968). Symbols are as in Fig. 20. see Tables 1 and 2 for data and references. 


$$
\frac{14}{V a}
$$


be rearranged and partitioned so that:

$$
\begin{aligned}
& \mathrm{T}_{\mathrm{b}}=\left(\mathrm{I}_{\mathrm{b}} / \mathrm{C}\right)_{\mathrm{o}}+\mathrm{K} \text { and } \\
& \mathrm{T}_{\mathrm{b}}=\left(\mathrm{M}_{\mathrm{b}} / \mathrm{C}\right)_{\mathrm{r}}\left(\mathrm{M}_{\mathrm{b}} / \mathrm{C}\right)_{e}+\mathrm{K}
\end{aligned}
$$

where $\mathrm{K}$ is the lower limit of thermoneutrality (MCNab, 1969, 1970).

Since equation (7) has the general form $y=a x+b$, the fit of available data to this model can be checked.

A biological check is also possible by rearranging equation

(7) so that:

$$
T_{b}-K=\left(I_{b} / C\right)_{r}\left(M_{b} / C\right)_{e}
$$

where $\mathrm{T}_{\mathrm{b}}$ measurements on the left side of the equation are compared with metabolic measurements on the right. Graphically represented, when $\left(\mathrm{T}_{\mathrm{b}}-\mathrm{K}\right)$ is plotted against $\left(\mathrm{M}_{\mathrm{b}} / \mathrm{C}\right) \mathrm{e}$ a line from the origin having a slope of $\left(\mathrm{M}_{b} / \mathrm{C}\right)_{r}$ should intercept the corresponding data point (Fig. 19). In a more dramatic way, when $\left(\mathrm{T}_{\mathrm{b}}-\mathrm{K}\right)$ is plotted against $\left(\mathrm{M}_{\mathrm{b}} / \mathrm{C}\right)_{\mathrm{r}}$ $\left(\mathrm{M}_{\mathrm{b}} / \mathrm{C}\right)_{e}$ (equation 8 ), the data should fall along a straight line having a slope of 1.0. In Figure 20, which is a plot of this relationship, the closeness of fit is evident.

\section{Determination of the Level of $T_{b}$}

It is apparent that $\mathrm{K}$ is determined by $\mathrm{M}_{\mathrm{b}}$ and $\mathrm{C}$, both by the weight factor $\left(\mathrm{M}_{\mathrm{b}} / \mathrm{C}\right)_{\mathrm{e}}$ and the relative ratio $\left(\mathrm{M}_{\mathrm{b}} / \mathrm{C}\right)_{\mathrm{r}}$. Therefore, adaptation to climatic and ecological conditions, along with $W$, sets the lower limit of the energetic quantity $\left(T_{b}-K\right)$. This difference is the buffer between the bird's regulated $\mathrm{T}_{\mathrm{b}}$ and the necessity for increasing energy expenditure. The magnitude of $\left(\mathrm{T}_{\mathrm{b}}-\mathrm{K}\right)$ is a good indicator of the 
Fig. 19. The relation of the extent of the thermal buffer to the thermoregulatory quotient expected from body size alone. Numbers at the left terminus of each line are slopes. The number accompanying each point is the $\left(\mathrm{H}_{\mathrm{b}} / \mathrm{C}\right)_{\mathrm{r}}$ value. The mean $\left(M_{b} / C\right)_{r}$ value for encircled points is equal to the slope of the line through the circle. symbols are as in Fig. 20. See T'ables 1 and 2 for data and references. 


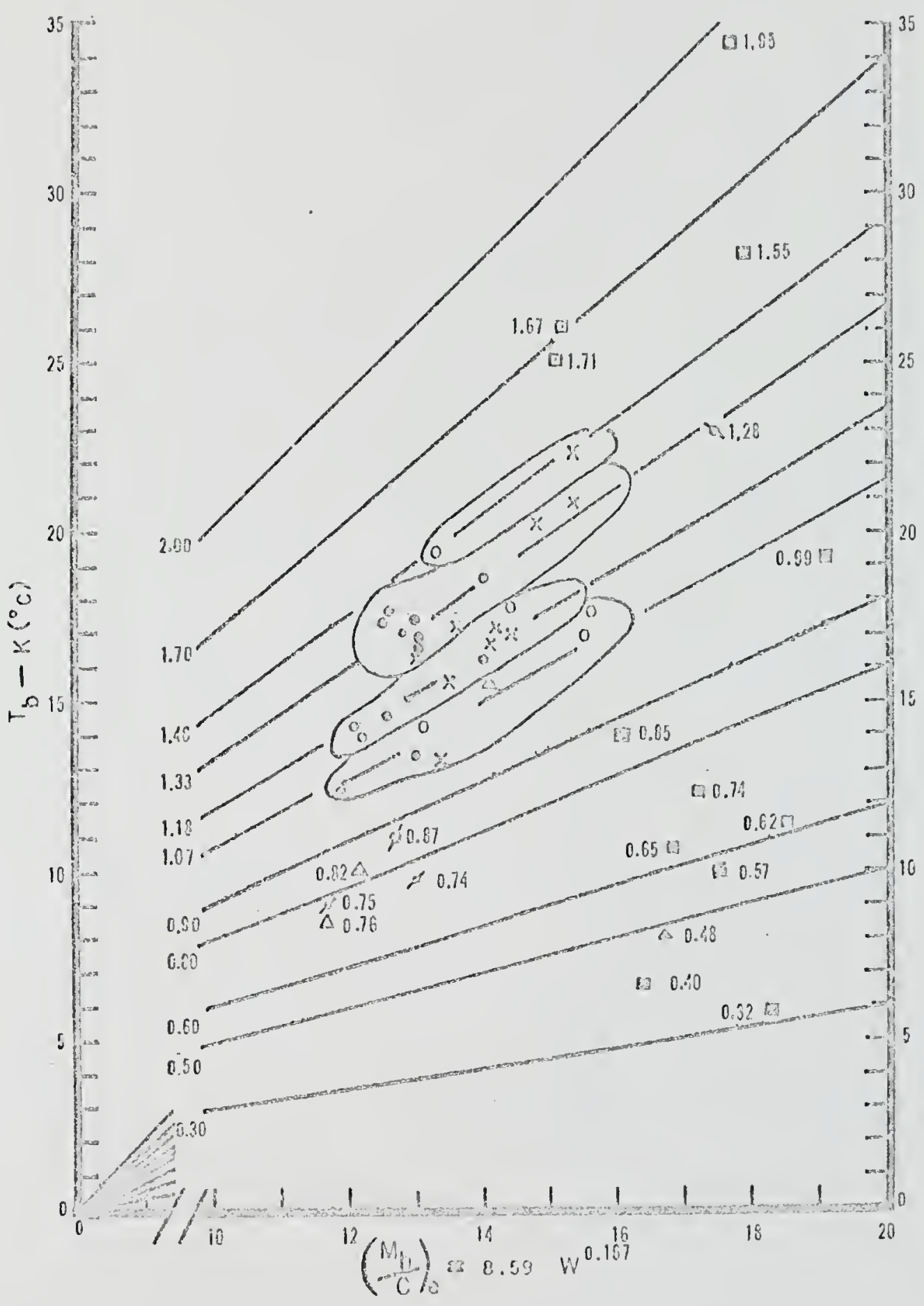


extent of cold stress to which a bird is subjected in its habitat.

The question as to whether $\mathrm{T}_{\mathrm{b}}$ is a dependent or independent parameter is more complex. It is logical to agree with Hammel's (1968) contention that an initial step in the evolution of homoiothermy vas necessarily the acquisition of an adequate insulation. Then, it becomes energetically feasible to invest in a fairly high ${ }^{1 \cdot I_{b}}$. The eventual thermoregulatory quotient and size of the endothermic avian stock likely resulted in $a\left(T_{b}-K\right)$ that was satisfactory for the thermal environment in which these animals lived. This original $\mathrm{T}_{\mathrm{b}}$ would have been dependent on $\mathrm{M}_{\mathrm{b}}, \mathrm{C}$, and $\mathrm{W}$. As the advantages of thermal homeostasis asserted themselves (whatever they may be), it is reasonable to assume that temperature-specific neural, enzymatic, and other systems also evolved. These systems could be more efficient if $\mathrm{T}_{\mathrm{b}}$ were precisely regulated. So, there must have been a parallel evolution of the energetic machinery making endothermy oossible and a regulating system that would maintain Tb stability in the interest of physiological efficiency. Ontogenetic evidence lends support to this speculation. Nestlings of some altricial species of birds show a chronological improvement in insulation, and at scme rather well-defined stage begin a rapid development of metabolic heat production and thermoregulatory capacity (e.g., Dawson and Evans, 1957, 1960; Yarbrough, 1970b). In cool environments, such nestlings first are able to regulate their $\mathrm{T}_{\mathrm{b}}$ at a J.ower level (e.g., $31-33^{\circ} \mathrm{C}$ ) than that of the adult 
(about $40{ }^{\circ} \mathrm{C}$ ). The regulated $\mathrm{T}_{\mathrm{b}}$ increases with age until the aduit level is achieved. So, it would seem that the regulatory mechanism becomes functional at a stage when $\left(M_{b} / C\right) \circ$ and $W$ reach an acceptable level, but the set point of the thermostat (the reference temperature for the regulating mechanism) is elevated as $\left(\mathrm{M}_{\mathrm{b}} / \mathrm{C}\right)_{\circ}$ and $\mathrm{W}$ increase.

For the original data presented here, as well as for the data from the literature, equation (6) predicts $\mathrm{T}_{\mathrm{b}}$ with an average error of only $0.3{ }^{\circ} \mathrm{C}$. One might well have expected experimental and mechanical error to exceed this value. Thus, the level of $\mathrm{T}_{\mathrm{b}}$ is very closely correlated with the interaction of $M_{b}, C$, and $w$ in birds, as it is in mammals (McNab, 1966b, 1969). However, I feel that the existing evidence does not warrant classification of $\mathrm{T}_{\mathrm{b}}$ as a completely dependent factor, except possibly in an evolutionary sense. Of course, it is true that in thermoneutrality a given $\mathrm{T}_{\mathrm{b}}$ depends on a particular balance of $\mathrm{C}$ and $\mathrm{M}_{b}$, but the $\mathrm{T}_{b}$ set point may influence the level of $\mathrm{M}_{b}$. The distinction lies between physical and physiological dependence. In the absence of the proper interrelations among $\mathrm{M}_{\mathrm{b}}, \mathrm{C}$, and $\mathrm{W}$, the thermostat is ineffectual. Under usual circumstances the regulating mechanism acts as a finetuning device within the limits prescribed by the thermal characteristics.

It mar be that the $\mathrm{T}_{\mathrm{b}}$ set point is an integral part of the evolutionary thermoregulatory complex, and, as a result, is to some extent adaptive. (In this case, $\mathrm{M}_{\mathrm{b}}, \mathrm{C}, \mathrm{W}$, and $\mathrm{T}_{\mathrm{b}}$ might be more accurately termed interdependent.) scholander 
et ar. (1950c) and most subsequent investigators have concluded that $\mathrm{T}_{\mathrm{b}}$ is non-adaptive, but there is now some evidence that mammalian $\mathrm{T}_{\mathrm{b}}$ levels may be capable of some adaptive variation independent of $!^{\prime} b$, $c$, and $w$ (i.icNab, 1970). However, the avian class apparently shows much less variation in $\mathrm{T}_{\mathrm{b}}$ than is the case in mammals. This reduces any adaptive effect of $\mathrm{T}_{\mathrm{b}}$, and increases the significance of ecological and cilimatic impact on $\mathrm{M}_{\mathrm{b}}$ and $\mathrm{C}$.

\section{Body Size Effects}

The impact of $w$ on thermal relations is considerable. This is largely due to the change in surface : volume ratio with weight. Surface area (A) is theoretically the most satisfactory unit for heat loss calculations, except that it is practically impossible to get an accurate estimate of $A$. This is especially true in birds, where one would have to decide what surface area must be considered. For example, what relation does $\mathrm{A}$ of the exposed parts (legs, head, beak) bear to the feathered surface? Alterations in peripheral circulation, particularly to the extremities, and postural changes complicate definition of the effective surface area. Use of $\mathrm{kr}^{2 / 3}$ as a value of $\mathrm{A}$ does nothing to solve these problems; it simply obscures them. merefore, it is considered that, at present, $w$ is the most undeceptive unit for discussing body-size relations in birds.

The relationship of $M_{b}$ to $w$ in small birds (<100 grams) has been described empirically by king and Farner. (1961) as following an equation equivalent to :

$$
\text { I"b }\left(\mathrm{ccO}_{2} / g-h r\right)=7.29 \mathrm{w}^{-0.341}
$$


where $W$ is in grams. Likewise, Lasiewski et al. (1967) considered $C$ to be related to $\mathrm{W}$ (grams) by the equation:

$$
\mathrm{C}\left(\mathrm{ccO}_{2} / \mathrm{g}-\mathrm{hr}{ }^{\circ} \mathrm{C}\right)=0.848 \mathrm{~W}-0.508
$$

which is similar to the $c$ equation of Herreid and Kessel (1967). Thus, both $M_{b}$ and $C$ increase as $W$ decreases. However, $\mathrm{M}_{\mathrm{b}}$ increases less rapidly with small size than does $C$, and the thermoregulatory quotient increases as W increases:

$$
\begin{aligned}
\left(M_{b} / C\right)_{e} & =7.29 w^{-0.341 / 0.848} w^{-0.508} \\
& =8.59 w^{0.167}
\end{aligned}
$$

where $w$ is in grams. So, it can be seen that a species can attain a given $\left(\mathrm{T}_{\mathrm{b}}-\mathrm{K}\right)$ either by adaptively changing $\left(\mathrm{M}_{\mathrm{b}} / \mathrm{C}\right)_{\mathrm{r}}$ or by possessing a suitable body size $\left(\mathrm{M}_{\mathrm{b}} / \mathrm{C}\right)_{e}$. The effect of $W$ on $\left(T_{b}-K\right)$ when $\left(M_{b} / C\right)_{r}$ is constant is shown in Figure 18.

MCNab (1969) suggested that there is a "critical" weight in mammals below which $T_{b}$ is dependent on $w$, but above which $T_{b}$ appears to be independent of $W$. Departure of $\left(M_{0} / C\right)_{r}$ from 1.0 can compensate for $W$ changes, and thus alter this "critical" weight. A "critical" weight is also indicated for birds (McNab, 1966a, 1970). So far as can be determined from published accounts and the data presented here, $\mathrm{T}_{\mathrm{b}}$ in birds appears to be $\mathrm{W}$-dependent throughout the size range, with the highest $\mathrm{T}_{\mathrm{b}}$ values occurring at about 20 grams. Above this size, $\mathrm{T}_{\mathrm{b}}$ declines very gradually, and below it, precipitously. Much of the data scatter is probably due to the $\left(M_{D} / C\right)_{r}$ effect. Apparently the "critical" 
weight is also variable. In warblers it occurs at 10-11 grams, in flycatchers at about 15 grams, and at 18-20 grams in sparrows. The significance of these apparent differences is not now obvious, although it may be similar to the case in mammals (McNab, 1970) in which temperate species have lower $\mathrm{K}$ values than tropical forms.

\section{Precision of $T_{b}$ Regulation}

The birds studied to date fall into two categories:

(I) those that regulate very well at moderate $\mathrm{T}_{\mathrm{a}}$ at all times until $\mathrm{W}$ (energy) loss results in weakening and death, and (2) those that regulate very well at $\mathrm{T}_{\mathrm{a}}$ of $10-30{ }^{\circ} \mathrm{C}$ but can go into torpor in times of stress or inactivity (humringbirds, goatsuckers, some swallows and swifts). Thus $\mathrm{T}_{\mathrm{b}}$ in birds would superficially appear to be less sensitive to $\mathrm{T}_{\text {a }}$ chariges than is the case in many mammals. It should be noted, however, that most of the species of birds which one would suspect as being poor thermoregulators are found in the tropics. The physiology of tropical birds is essentially untouched.

Birds employed in the present study are adequate to good thermoregulators. The change in $\mathrm{T}_{\mathrm{b}}$ per unit change in $\mathrm{T}_{\mathrm{a}}$ $\left(\Delta \mathrm{T}_{\mathrm{b}} / \Delta \mathrm{T}_{\mathrm{a}}\right)$ is a measure of the sensitivity of $\mathrm{T}_{\mathrm{b}}$ to $\mathrm{T}_{\mathrm{a}} \cdot$ Figure 21 shows that there is little change in $\mathrm{T}_{b}$ over $\mathrm{T}_{\mathrm{a}}$ from $30^{\circ}-10^{\circ} \mathrm{C}$. Although there is a greater change in the smaller species of each family or those having a low $\left(M_{\mathrm{D}} / \mathrm{C}\right)_{r}$, the poorest thermoregulator is precise when compared with values for some mammals (MCNab, 1965b, 1969). Values of $\Delta \mathrm{T}_{\mathrm{b}} / \Delta \mathrm{T}_{\mathrm{a}}>$ 0.10 are found only in those species with both very small 
Fig. 20. A plot of the extent to which body temperature is buffered, as a function of the combined ratios $\left(\mathrm{M}_{\mathrm{b}} / \mathrm{C}\right)_{\mathrm{r}}$ and $\left(\mathrm{Mb}_{\mathrm{b}} / \mathrm{C}\right)_{e}$. The line is expected from Newton's law of heat loss. See 'rables 1 and 2 for data and references. 


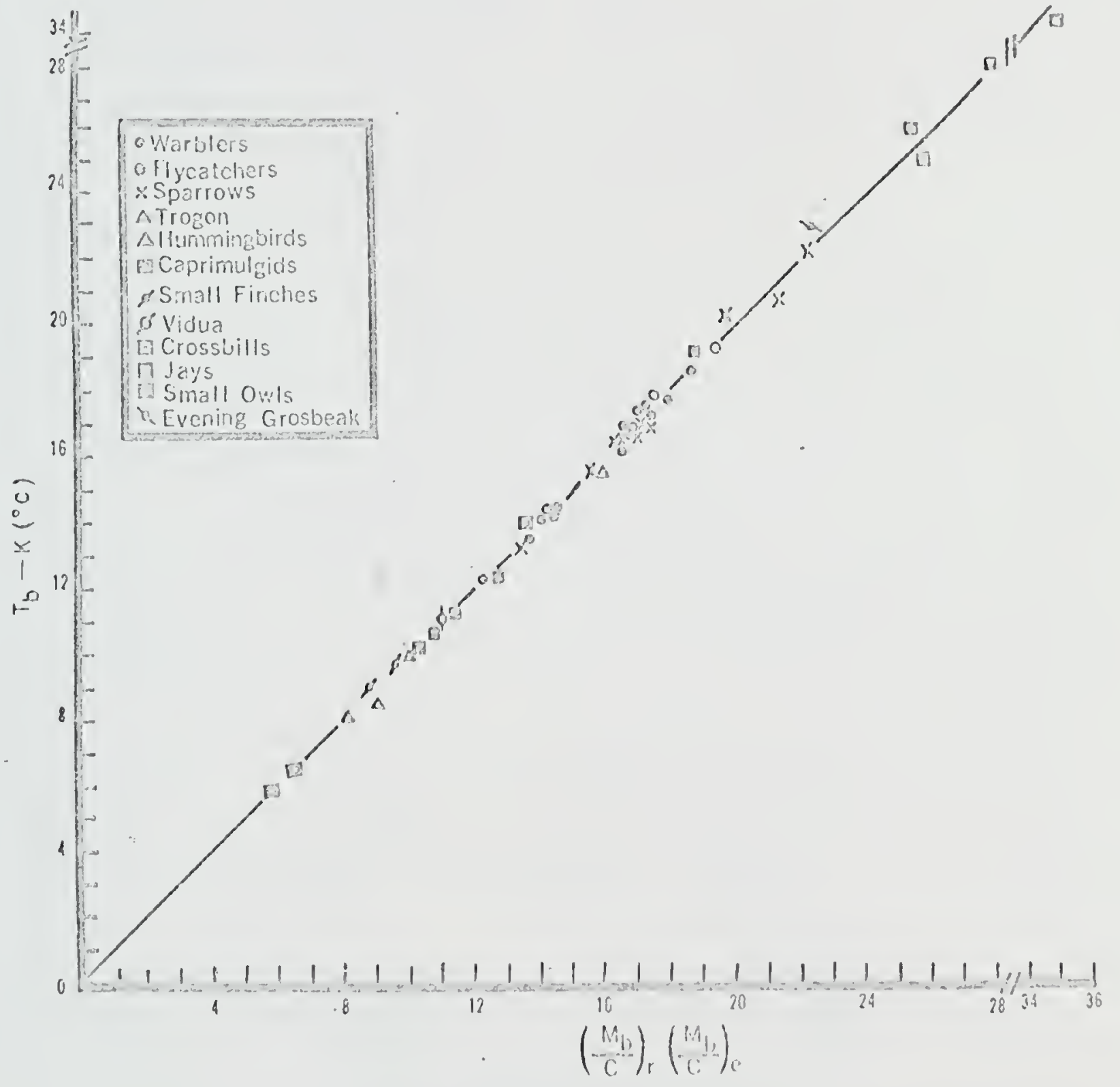


Fig. 21. A plot of the degree of sensitivity of body temperature to changes in ambient temperature $\left(\Delta \mathrm{T}_{\mathrm{b}} / \Delta \mathrm{T}_{\mathrm{a}}\right)$ as a function of body size $\left(\mathrm{H}_{\mathrm{b}} / \mathrm{C}\right)_{\mathrm{e}}$ in some small birds.

Fig. 22. The relation of body weight and the ratio $\left(M_{b} / C\right)_{r}$ to the lower limit of thermoneutrality. Arrows inaicate the climatic zone which is the wintering limit for each general food habit type. See the text for further explanation, and Tables 1 and 2 for data and references. Symbols are as in Fig. 20. 


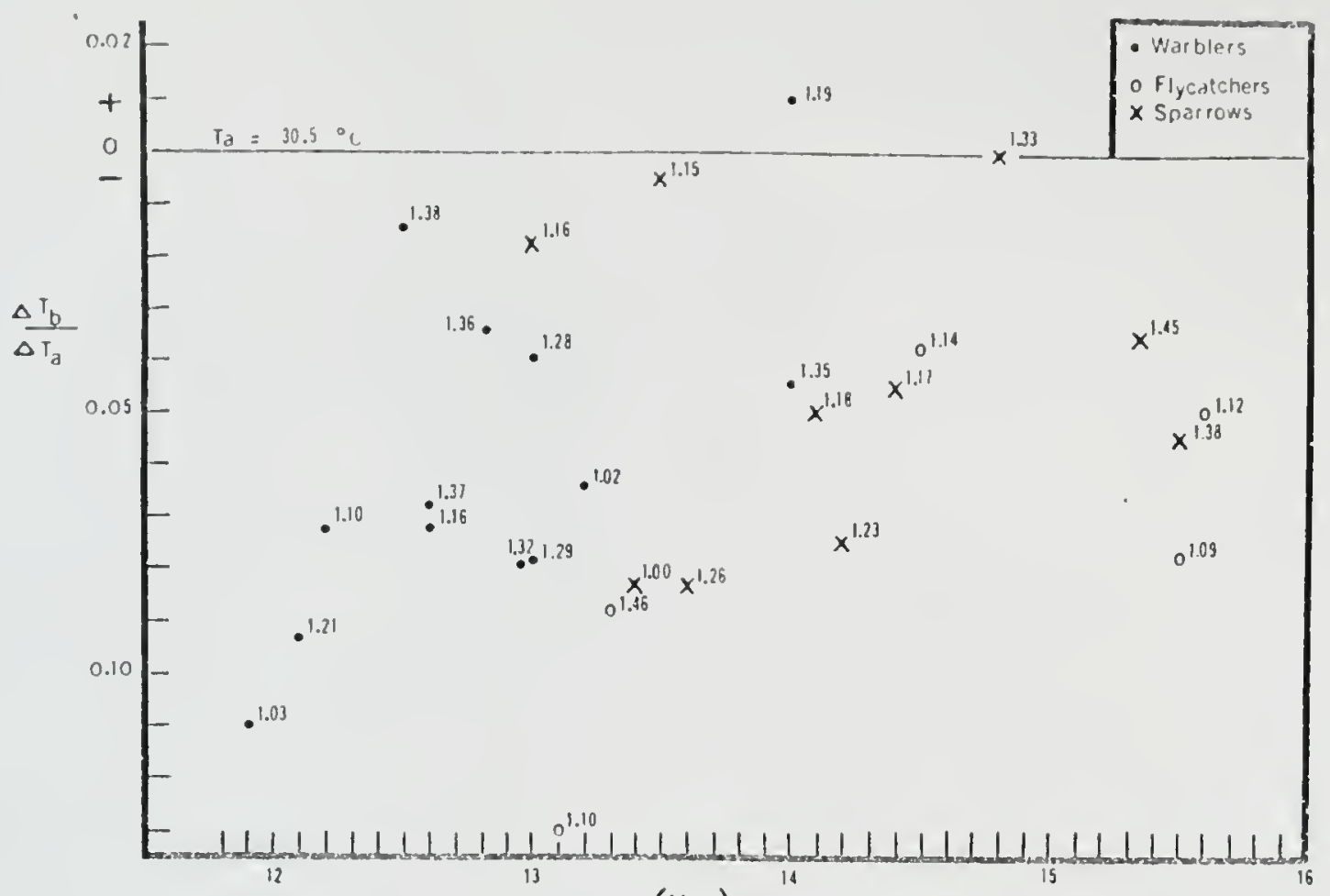

50

$$
\left(M_{b} / c\right)_{e}=8.59 w^{0.161}
$$

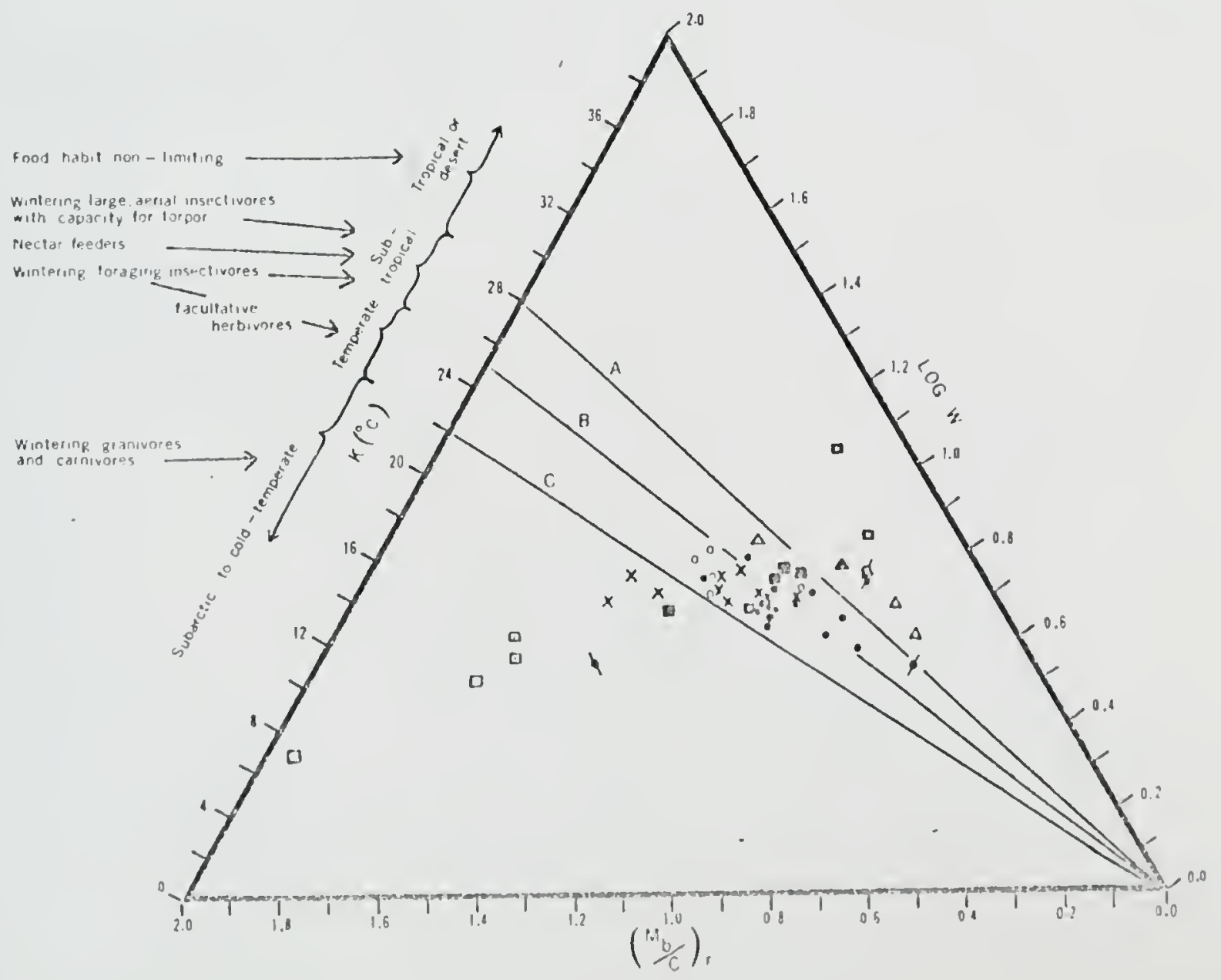


body size and low $\left(\mathrm{M}_{\mathrm{b}} / \mathrm{C}\right)_{r}$, the Parula Warbler and the Acadian Flycatcher.

The amount of energy reserves (fat) is an important factor in the precision of regulation. Neight deviations greater than five per cent from the species mean are positively correlated with $\mathrm{T}_{\mathrm{b}}$ deviations greater than $0.5^{\circ} \mathrm{C}$ from the species mean. Such an analysis will account for 83 per cent of the variation in warblers, 77 per cent in flycatchers, 61 per cent in Zonotrichia sparrows, and 100 per cent in sparrows smaller than 20 grams.

Adults of small species with altricial young probably live near the limits of their energy reserves during the breeding season, particularly during the nestling period. This is an especially acute problem for insectivorous species, if that season happens to have frequent inclement weather. The frequency of thunderstorms during the nestling period of 1969 was abnormally high in eastern North Carolina. Results of several metabolic tests of the small flycatchers (particularly the Acadian) had to be discarded because the birds were in such poor nutritional condition. If Acadians were captured before noon prior to nocturnal testing, sometimes they would weaken and die by the following morning. Even in a species that forages and flycatches, such as the Blackpoll warbler (Dendroica striata), body lipid content may be almost completely exhausted during parts of the breeding season (Yarbrough, 1970a).

Ecological and Distributional Relationships

Some of the ways in which ecology and climate may affect 
the behavior of various thermoregulatory parameters have been discussed above. It is my intent in this section to summarize some of the general relationships that exist between the physical model and patterns of avian distribution.

Consideration of all the factors in the heat loss model accurately accounts for non-experimental variation in the data (Fig. 20). The various species spread out along the theoretical line, with very small birds or desert and tropical species nearest the origin, and birds that are larger or adapted to cold $\mathrm{T}_{\mathrm{a}}$ farthest from the origin.

A more meaningful representation of this information is given in Figure 22. The lowest thermoneutral $\mathrm{T}_{\mathrm{a}}$ for a species is connected with the origin. The data point is placed where this line intersects a line between the weight and $\left(M_{b} / C\right)_{r}$ characteristics for the species under consideration. These thermoregulatory parameters can then be related to climatic or latitudinal distribution. The climatic zone which is the winter thermal limit for birds havirg certain food habits is also indicated. The picture could be more precise if we understood the impact of ecological factors other than food habit on the distribution of birds.

Lines A, B, and C are empirical thermo-ecologic boundaries for small birds un to about 100 grams in weight. Wovement from one zone to another is possible by changing $w$ or $\left(\mathrm{H}_{\mathrm{b}} / \mathrm{C}\right)_{\mathrm{r}}$. For example, the birds in the tropical-desert 
zone are not generally cold-stressed in nature and have become adapted for coping with heat stress and water scarcity. This may involve being very smali (small finches and Paradise Widowbird) or having a low thermal index $\left(\mathrm{T}_{\mathrm{b}}-\mathrm{K}\right)$, such as that of the Black-throated Trogon and some caprimulgids. The capacity for torpor serves as a buffer to reduce energy outlay in times of food deprivation and occasional cool weather.

Birds wintering in the cold-temperate to subarctic zone must have a high $\left(\mathbb{K}_{\mathrm{b}} / \mathbb{C}\right)_{\mathrm{r}}$ and cannot be smaller than about ten grams. The thermoregulation of northern chickadees (Farus hudsonicus and $P$. cinctus) shoulda be examined from this standpoint. Food habit is usually limiting in this zone, since only herbivores and carnivores (including scavengers, such as gulls and ravens) are found here. Steen (1958) has found that some small, cold-climate species can allow $\mathrm{T}_{\mathrm{b}}$ to drop as low as $30^{\circ} \mathrm{C}$ at night as an energy conservation measure. He also suggests that under natural conditions these birds avoid severe cold stress by means of their roosting habits.

The majority of species used in this study fall into the temperate zone, having $\mathrm{K}$ values between $22^{\circ}$ and $25^{\circ} \mathrm{C}$. It is of interest to note that all the flycatchers studied, except the Acadian, are thermally capable of wintering in the temperate zone. This is an obvious case of avian distribution being limited by focd habit (and possibly evollitionary history). The warblers that winter as far north as 
the southeastern U. S. fall into zone C (temperate), whereas those that winter from the Caribbean area southward fall into the subtropical zone on the graph. The winter range of the Pauraque does not extend as far north as that of the Poor-will. Yet, on a thermal basis the Pauraque is much better equipped to regulate at low $\mathrm{T}_{\mathrm{a}}$. It would be germane to know if the Pauraque can or does enter torpor as readily as the Poor-will. The lower $\mathrm{M}_{\mathrm{b}}$ of the Poor-will may indicate a greater external heat load than is true for the Pauraque.

The three small owls of the southwestern U. S. and Mexico that have been studied are distributed as one would predict from Eigure 22. The Saw-whet has thermoregulatory characteristics that coincide with its actual cold-temperate distribution. The Giant Humningbird has the thermal capability for a subtropical distribution, instead of tropical as is the case with smaller humingbirds. Its actual distribution extends from the montane tropics southward into Peru and Chile. Range extension of some humingbirds beyond the thermal limits suggested by their thermoregulatory parameters is probably due to their capacity for torpor.

The present state of knowledge concerning $\mathrm{T}_{\mathrm{b}}$ regulation in birds does not allow conclusions to the effect that food habits jetermine thermoregulatory capacity, as they apparently do in bats (McNab, 1969). Food habit mainly affects the distribution of most birds studied to date. Species with seasonal food problems usually migrate; thus, thermoregulatory 
adaptation is unnecessary. There may be correlations of food habit with ${ }^{M}$ and $C$ in some species, but other factors such as heat and water stress would complicate any analysis. In birds, it appears that thermoregulatory parameters are adapted primarily to climate, and are only indirectly or secondarily related to food habit. Therefore, large climatic differences must not be introduced into data that are used to determine the impact of ecology on thermoregulation. Such data have not yet been gathered. Consequently, the need is obvious for extensive studies on tropical birds of all sizes, ecological characteristics, and taxonomic affiliations. 
The energetics of $\mathrm{T}_{\mathrm{b}}$ regulation in small birds are accurately described by the Newtonian model of heat loss. A thermoregulatory quotient $\left(\mathrm{M}_{\mathrm{b}} / \mathrm{C}\right)_{0}$ which considers both heat production and the coefficient of heat loss is a more satisfactory indication of thermoregulatory capacity than either parameter alone.

Climatic and ecological adaptations of these parameters are indicated by $\left(\mathrm{M}_{\mathrm{b}} / \mathrm{C}\right)_{I}$, which compares $\left(\mathrm{H}_{\mathrm{b}} / \mathrm{C}\right)_{0}$ to the value ( 1.00$)$ expected from $W$ alone $\left(M_{\mathrm{b}} / C\right)$ e. Tropical and desert species generally have low $\left(M_{b} / C\right) r$, and birds that must tolerate cold climates have high values. Birds living in cool climates may partially compensate, within limits, for low $\left(\mathrm{N}_{\mathrm{b}} / \mathrm{C}\right)_{\mathrm{C}}$ by having an increased body size $\left(\mathrm{M}_{\mathrm{b}} / \mathrm{C}\right)_{\mathrm{e}}$, the capacity for torpor, or both.

$M_{b}$ may be lower than expected in desert species mainly to reduce the heat load and evaporative water loss. Tropical, non-desert species may also have a lower $M_{b}$ than expected for other birds in order to reduce the heat load, to conserve energy (if the food supply is unreliable), or simply because they are not faced with the need for a higher rate of heat production. Some cool-climate birds may also have a reduced ${ }^{M}$ bo conserve energy. This is particularly true if the birds are very small and dependent 
on a variable food source (such as insects). In this case, $C$ is also reduced. It is suggested that $M_{b}$ differences between any two avian groups are actually correlated with ecological and climatic differences in the birds sampled, not taxonomy per se.

$C$ is generally high in tropical and desert forms, and low in cold-climate species. However, the effect of environmental stress on $\mathrm{M}_{b}$ may militate against this strategy in some cases. Likewise, $M_{b}$ cannot be radically altered if the environment precludes compensatory changes in $C$. $M_{b}$ and $C$ must evolve as complementary thermal parameters.

The level of $\mathrm{T}_{\mathrm{b}}$ is very closely correlated with $\mathrm{M}_{\mathrm{b}}$, $\mathbb{C}$, and $W$. Non-torpid birds are very precise thermoregulators, as compared to most mammals. A combination of very small body size and a low $\left(\mathrm{M}_{\mathrm{b}} / \mathrm{C}\right)_{r}$ may reduce the precision of $\mathrm{T}_{\mathrm{b}}$ regulation, as may a drastic loss of iw during extended food deprivation.

Presently available information indicates that the distribution of avian species outside the tropics and deserts is limited by ecology, particularly food habits. Thermoregulatory parameters are primarily adapted to climate. Thus, in order to determine the extent to which food habit can affect thermoregulation, significant climatic differences must be circumvented. The ecological impact on $\mathrm{T}_{\mathrm{b}}$ regulation in birds must remain poorly understood pending investigation of tropical faunas. 
APPENDICES 
APPENDIX A

Symbols and Expressions Employed in This Paper

Symbol

Description

Units

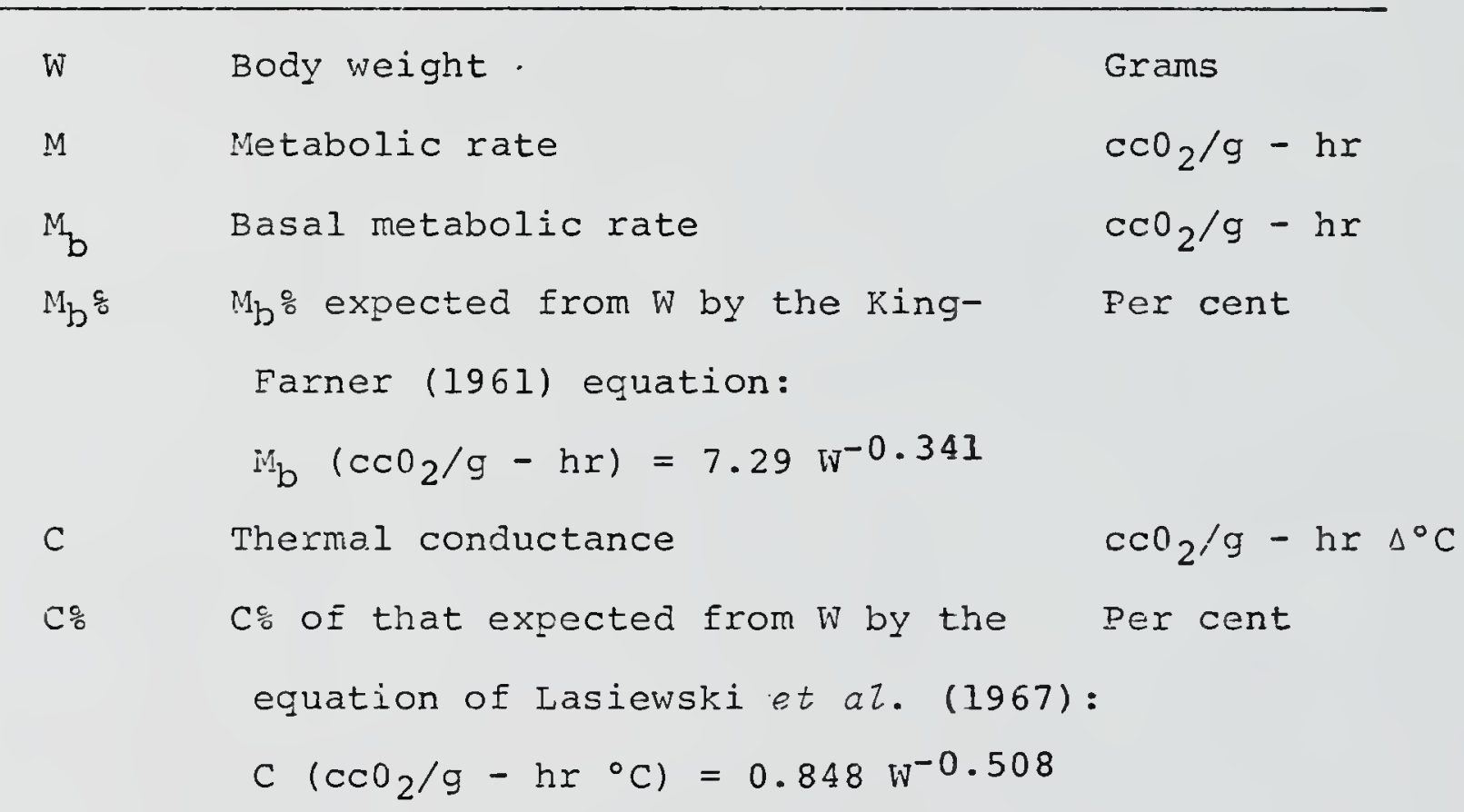

$\left(\mathrm{M}_{\mathrm{b}} / \mathrm{C}\right)_{\circ}$ Observed thermoregulatory quotient ${ }^{\circ} \mathrm{C}$

$\left(\mathrm{M}_{\mathrm{b}} / \mathrm{C}\right)_{\mathrm{e}}$ Thermoregulatory quotient expected ${ }^{\circ} \mathrm{C}$

from $W$ by the King-Farner and

Lasiewski et al. equations (see

above $):\left(\mathrm{M}_{\mathrm{b}} / \mathrm{C}\right)_{\mathrm{e}}=8.59 \mathrm{w}^{0.167}$

$\left(M_{b} / C\right)_{r}$ Relative thermoregulatory quotient None

$$
\left(\mathrm{M}_{\mathrm{b}} / \mathrm{C}\right)_{\mathrm{o}} /\left(\mathrm{M}_{\mathrm{b}} / \mathrm{C}\right)_{\mathrm{e}}
$$

$\mathrm{T}_{\mathrm{b}} \quad$ Body temperature

$\mathrm{T}_{\mathrm{a}} \quad$ Ambient temperature

$$
\begin{aligned}
& { }^{\circ} \mathrm{C} \\
& { }^{\circ} \mathrm{C}
\end{aligned}
$$


APPENDIX A

(continued)

Symbol

Description

Units

$\Delta \mathrm{T}_{\mathrm{b}} / \Delta \mathrm{T}_{\mathrm{a}} \quad$ Change in body temperature per unit None change in ambient temperature

$\mathrm{K} \quad$ Lower limit of thermoneutral zone ${ }^{\circ} \mathrm{C}$

$\mathrm{T}_{\mathrm{b}}-\mathrm{K} \quad$ Extent of thermal buffering ${ }^{\circ} \mathrm{C}$

$\begin{array}{ll}Q_{L} \text { Heat loss } & \mathrm{CCO}_{2} / 9 \text { or } \\ & \mathrm{cal} / \mathrm{g}\end{array}$

$t \quad$ Time

Hours

k Cooling constant

$1 /$ hours

A Surface area

$\mathrm{cm}^{2}$

c Speciric heat

$\mathrm{CCO}_{2} / \mathrm{g}{ }^{\circ} \mathrm{C}$ or

$\mathrm{cal} / \mathrm{g}{ }^{\circ} \mathrm{C}$ 


\section{APPENDIX B}

Scientific and Common Names for species Discussed in This Study

Species for Which Original Data Are Presented

Sparrows

Spizezla passerina

Chipping $(W)^{l}$

Ammodramus savannarum

Grasshopper

(W)

Me Zospiza meZodia

Song (W)

M. georgiana

Swamp (W)

Passerculus sandwichensis

Savannah (W)

Pooecetes gramineus

Vesper (W)

Zonotrichia albicolzis

White-throated

2. Zeucophrys

White-crowned

2. queruza

Harris ${ }^{\prime}$

(W)

Passerelza iliaca

Fox (N)

Flycatchers

Empidonax virescens

Acadian (S)

Contopus virens

Wood Pewee (S)

Sayornis phoebe

Phoebe (W)

Myiarchus crinitus

Crested (S)

Tyranius tyrannus

E. Kingbird

(S)

1 The symbols indicate the time of year when species were captured and studied: (W) winter, (S) sumer, (M) migrant, not in Zugunruhe. 
APPENDIX B

(continued)

Wood Warblers

Parula americana

Vermivora pinus

V. celata

Mniotizta varia

Dendroica dominica

D. palmarum

D. coronata

D. pinus

Geothrypis trichas

"Iizsonia citrina

Protonotaria citrea

s. aurocapizzus
Seiurus noveboracensis

Parula (S)

Blue-winged

Orange-crowned

Black-and-white

Yellow-throated

Palm (IN)

Myrtle (W)

Pine (IV)

Yellowthroat (W)

Hooded (S)

Prothonotary

II. Waterthrush

(M)

Ovenbird (M)

Trogon

Trogon rufus

Black-throated

Species for Which Data Wexe Obtained from the I,iterature

otus trichopsis

Whiskered Owl

Glaucidium gnoma

Pygmy Owl

Micrathene whitneyi

Elf OWl

Aegolius acadicus

Saw-ivhet Owl

Phalaenoptizus nuttalzii

Poor-will

Nyctidromus albicolzis

paurague

chordeiles minor

Common Nighthawk

Eurostopodus guttatus 


\section{APPEINDIX B}

(continued)

Eugenes furgens

Lampornis clemenciae

Patagona gigas

viàua paradisea

Perisoreus canadensis

Cyanocitta cristata

Hesperiphona vespertina

Loxia curvirostra

L. Zeucoptera

Taeniopygia castanotis

Estrilda troglodytes
Rivoli's Hummingbird

Blue-throated Hummingbird

Giant Hummingbira

Paradise Widowbird

Gray Jay

N. Blue Jay

Evening Grosbeak

Red Crossbill

White-winged Crossbill

Zebra Finch

Black-rumped Waxbill 
RTEEREIV̈CES

Bartholomew G. A., Hudson J. W. \& Howell T. R. 1962. Body temperature, oxygen corsumption, evaporative water loss, and heart rate in the poor-will. condor 64, 117-125.

Bartholomew G. A. \& Tucker V. 1964. Size, body temverature, thermal. conductance, oxygen consumption, and heart rate in Pustralian varanid lizards. Physiol. Zool. $37,341-354$.

Bent A. C. 1942. Life histories of North American Elycatchers, larks, swallows and their allies. U. S. Natz. Mus. Buzz. 179, 140-154.

Bent A. C. 1953. Life histories of North American wood warblers. U. S. NatZ. Mus. BuZZ. 203, 239-258.

Burtor A. C. 1934. The application of the theory of heat flow to the study of energy metabolism. Jour. Nutrition 7, 497.

Calder W. A. 1964. Gaseous metabolism and water relations of the zebra finch, Taeniopygia castanotis. Physiol. 200Z. $37,400-413$.

Dawson W. R. E Evans F. C. 1957. Relation of growth and development to temperature regulation in nestling field and chipping sparrows. Physiol. Zool. 30, 315-327.

Dawson W. R. à Evans F. C. 1960. Relation of growth and development to iemperature regulation in nesting vesper sparrows. Conäor $62,329-340$.

Dawson W. R. \& Tordoff H. B. 1964. Relation of oxygen consumption to temperature in the red and whitewirlged crossbilis. Auk $81,26-35$.

Dawson W. R. \& Fisher C. D. 1969. Responses to temperature by the spotted nigitjar (Eurostopodus guttatus). concior $71,49-53$.

Hamilton W. J., III \& Heppner F. H. 1967. Fadiant solar energy and the function of black homeotherm pigmentation: an hypotinesis. Science 155, 196-197. 
Hammel H. T. 1968. Regulation of internal body temperature. Ann. Rev. Physioz. 30, 641-710.

Hart J. S. 1957. Climatic and temperature induced changes in the energetics of homeotherms. Rev. Can. Biol. $16,133-174$.

Heppner F. H. 1970. The metabolic significance of differential absorption of radiant energy by black and white birds. Condor 72, 50-59.

Herreid C. F., II \& Kessel B. 1967. Thermal conductance in birds and mammals. Comp. Biochem. Physiol. 21, 405-414.

Hudson J. W. \& Kimzey S. L. 1964. Body temperature and metabolism cycles in the house sparrow, Passer domesticus, compared with the white-throated sparrow, Zonotrichia albicollis. Amer. Zool. 4, 294-295.

Johnson R. E. 1968. Temperature regulation in the whitetailed ptarmigan, Lagopus Zeucurus. Comp. Biochem. Physioz. 24, 1003-1014.

King J. R. 1964. Oxygen consumption and body temperature in relation to ambient temperature in the whitecrowned sparrow. Comp. Biochem. Physiol. 12, 13-24.

King J. R. \& Farner D. S. 1961. Energy metabolism, thermoregulation, and body temperature. In Biology and. Comparative Physiology of Birds (Edited by Marshall, A. J.), Vol. 2, pp. 215-288. Academic Press, New York.

Kleiber 1. 1961. The Fire of Life. John Wiley, New York.

Lasiewski R. C., Hubbard S. H. \& Moberly W. R. 1964. Energetic relationships of a very small passerine bird. Condor 66, 212-220.

Lasiewski R. C. \& Dawson W. R. 1964. Physiological responses to temperature in the common nighthawk. Condor 66, $477-490$.

Lasiewski R. C. \& Dawson W. R. 1967. A re-examination of the relation between standard metabolic rate and body weight in birds. Condor 69, 13-23.

Lasiewski R. C. \& Lasiewski R. J. 1967. Physiological responses of the blue-throated and Rivoli's hummingbirds. Auk 84, 34-48.

Lasiewski R. C., Weathers W. W. \& Bernstein M. H. 1967. Physiological responses of the giant hummingirird, Patagona gigas. Comp. Biochem. Physiol. 23, 797-813. 
Ligon J. D. 1968. The biology of the el藏 owl, Micrathene whitneyi. Univ. Michigan Mus. Zool. Misc. Pubz. 136.

Ligon J. D. 1969. Some aspects of temperature relations in small owls. Auk 86, 458-472.

McNab B. K. 1966a. An analysis of the body temperature of birds. Condor 68, 47-55.

McNab B. K. 1966b. The metabolism of fossorial rodents: a study of convergence. Ecology 47, 712-733.

McNab B. K. 1969. The econoinics of temperature regulation in neotropical bats. Comp. Biochem. Physiol. 31 , 227-268.

MCNab B. K. 1970. Body weight and the energetics of temperature regulation. Submitted for publication.

McNab B. K. \& Morrison P. R. 1963. Body temperature and metabolism in suospecies of Peromyscus from arid and mesic environments. Ecol. Monographs 33, 63-82.

Misch M. S. 1960. Heat regulation in the northern blue jay, Cuanocitta cristata bromia Oberholser. Physioz. zooz. 33, 252-259.

Pearson O. P. 1950. The metabolism of hummingbirds. Condor 52, 145-152.

Rising J. D. 1958. The effect of temperature variation on the metabolic activity of the Harris' sparrow. Comp. Biochem. Physiol. 25, 327-333.

Scholander P. F., Walters V., Hock R. \& Irving I. 1950 . Body insulation of some arctic and tropical mammals and birds. Biol. Eulz. 99, 225-236.

Scholander P. F., Hock R., Walters V., Johnson F. \& Irving I. $1950 \mathrm{~b}$. Heat regulation in some arctic and tropical mammals ard birds. Biol. Bulz. 99, 237-258.

Scholander P. F., Hock R., waiters V. \& Irving L. 1950c. Adaptation to cold in arctic and tropical mamnils and birds in relation to body temperature, insulation and basal metabolic rate. Biol. Buiz. 99, 259-27].

Steen J. 1958. Climatic adaptation in some sinall northern birds. Ecology 39, 625-629.

Veghte J. H. 1964. Thermal and netabolic responses of the gray jay to cold stress. Physiol. Zool. 37, 316-328. 
Wallgren H. 1954. Energy metabolism of two species of the genus Emberiza as correlated with distribution and migration. Acta 200Z. Fenn. 84, 1-110.

West G. C. \& Hart J. S. 1966. Metabolic responses of evening grosbeaks to constant and to fluctuating temperatures. Physiol. 200l. 39, 171-184.

Yarbrough C. G. 1970a. Sumer lipid levels in some breeding subarctic birds. Auk 87, 100-110.

Yarbrough C. G. 1970b. The development of endothermy in nestling gray-crowned rosy finches, Leucosticte tephrocotis griseonucha. Comp. Biochem. Physiol. 33.

Yarbrough C. G. \& Johnston D. W. 1965. Lipid deposition in wintering and premigratory myrtle warblers. Wizson Buzz. 77, 175-191. 
BIOGRAPHICAL SKETCH

Charles Gerald Yarbrough was born Gctober 13, 1939, at Lumberton, North Carolina. He was graduated from Bladenboro High School (N. C.) in May, 1957. In June, 1961, he received the degree of Bachelor of science with a major in Biology from Wake Forest University. From 1961 until 1963 he was a teaching assistant and graduate fellow at Wake Forest, where he received the Master of Arts degree in Biology in June, 1963. He attended the University of Michigan as a teaching fellow during the academic year 1963-1964. During the summer of 1964 he did ecological research in the Canadian subarctic or a Chapman research grant from the American liuseum of Natural History. He was employed as Instructor in Biology at Campbell college for two years, $1964-65$ and 1966-67. During 1965-66 he worked ass an Interim Instructor in zoology at the University of Florida. From September, 1967, until the present time he has pursued his work toward the degree of Doctor of Philosophy while j.n tenure of a National Science Foundation Traineeship at the University of Floria. In 1968, he wo:ked as an avian ecologist at. an Atomic Energy Commission project on Amchitka Island, Alaska.

Charles Gerald Yarbrough is married to the former Hazel Ruth Hill, and is the father of two sons. He is a member of 
Sigma Xi, Phi Sigma, the American Ornithologists' Union, the Cooper Ornithological Society, and the wilson ornithological Society. 
This dissertaticn was prepared under the direction of the chairman of the candiate's supervisory committee and has been approved by all members of that committee. It was submitted to the Dean of the College of Arts and Sciences and to the Graduate Council, and was approved as partial fulfillment of the requirements for the degree of Doctor of Philosophy.

June, 1970

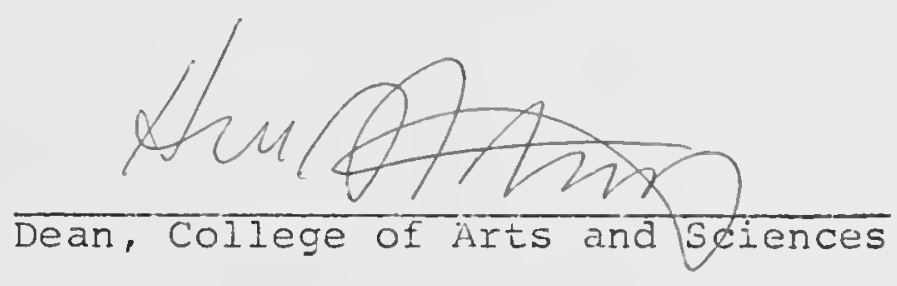

Dean, Graduate School

Supervisory Committee:
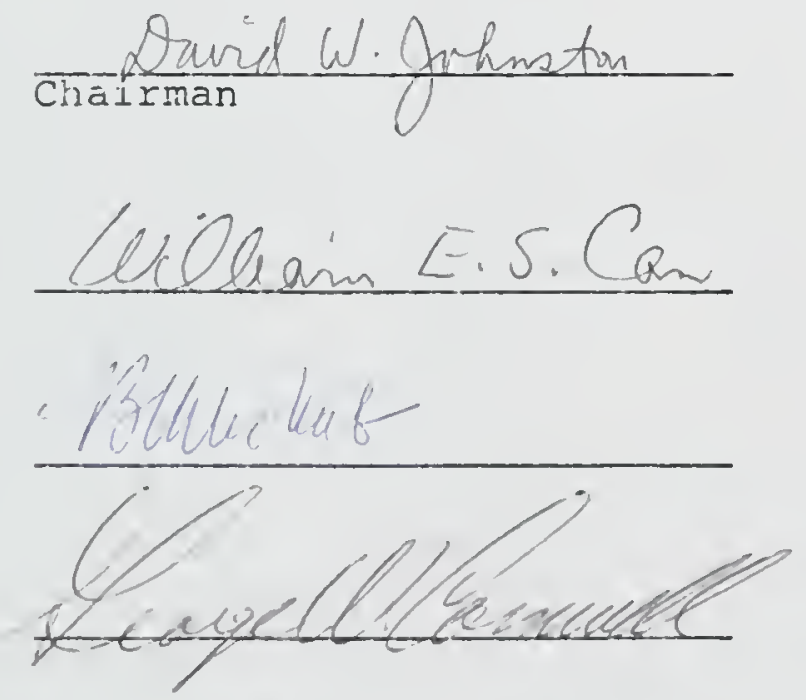

